\title{
Arbeidsmarktmonitor Apotheekbranche Verkenning opzet tweede cyclus (2003-2005)
}

Citation for published version (APA):

Sanders, J. M. A. F., Sieben, I. J. P., \& de Grip, A. (2003). Arbeidsmarktmonitor Apotheekbranche Verkenning opzet tweede cyclus (2003-2005). Researchcentrum voor Onderwijs en Arbeidsmarkt, Faculteit der Economische Wetenschappen. ROA Working Papers No. 002 https://doi.org/10.26481/umarow.2003002

Document status and date:

Published: 01/01/2003

DOI:

10.26481/umarow.2003002

Document Version:

Publisher's PDF, also known as Version of record

\section{Please check the document version of this publication:}

- A submitted manuscript is the version of the article upon submission and before peer-review. There can be important differences between the submitted version and the official published version of record. People interested in the research are advised to contact the author for the final version of the publication, or visit the DOI to the publisher's website.

- The final author version and the galley proof are versions of the publication after peer review.

- The final published version features the final layout of the paper including the volume, issue and page numbers.

Link to publication

\footnotetext{
General rights rights.

- You may freely distribute the URL identifying the publication in the public portal. please follow below link for the End User Agreement:

www.umlib.nl/taverne-license

Take down policy

If you believe that this document breaches copyright please contact us at:

repository@maastrichtuniversity.nl

providing details and we will investigate your claim.
}

Copyright and moral rights for the publications made accessible in the public portal are retained by the authors and/or other copyright owners and it is a condition of accessing publications that users recognise and abide by the legal requirements associated with these

- Users may download and print one copy of any publication from the public portal for the purpose of private study or research.

- You may not further distribute the material or use it for any profit-making activity or commercial gain

If the publication is distributed under the terms of Article $25 \mathrm{fa}$ of the Dutch Copyright Act, indicated by the "Taverne" license above, 


\title{
Arbeidsmarktmonitor Apotheekbranche Verkenning opzet tweede cyclus (2003-2005)
}

\author{
ROA-W-2003/2
}

Jos Sanders, Inge Sieben, Andries de Grip

\section{Researchcentrum voor Onderwijs en Arbeidsmarkt}

Faculteit der Economische Wetenschappen en Bedrijfskunde Universiteit Maastricht

Maastricht, juni 2003 
ISBN 90-5321-372-4

Sec03.067.doc 


\section{Inhoud}

Voorwoord

1 Inleiding 1

2 Relevante aandachtsgebieden 2

2.1 Algemeen 2

2.2 Knelpunten op de arbeidsmarkt en personeelsbeleid in de openbare apotheek 3

2.3 Werken in de openbare apotheek 6

2.4 Schoolverlaters 10

2.5 Onbenut arbeidspotentieel 10

$\begin{array}{ll}2.6 \text { Toekomstverkenning } & 13\end{array}$

3 Doelgroepen en onderzoeksvragen 13

$\begin{array}{ll}3.1 \text { Doelgroepen } & 16\end{array}$

3.2 Overige aandachtspunten 22

4 Opzet tweede cyclus $\quad 28$

4.1 Werkgeversonderzoek 28

4.2 Werknemersonderzoek 32

4.3 Schoolverlatersonderzoek 36

4.4 Onderzoek onder niet-participerenden $\quad 37$

4.5 Toekomstverkenning 39

$\begin{array}{ll}\text { 4.6 Mogelijke nieuwe instrumenten } & 40\end{array}$

4.7 Overzicht instrumenten Arbeidsmarktmonitor Apotheekbranche 41

Bijlage 1: Gesprekspartners $\quad 43$ 



\section{Voorwoord}

Dit rapport is onderdeel van de arbeidsmarktmonitor voor de openbare apotheek, waarvan recentelijk de eerste cyclus is afgerond. In het kader van deze eerste cyclus is een vijftal rapporten uitgebracht. ${ }^{1}$ Voor het uitvoeren van de verkenning voor een opzet voor de tweede cyclus, waarvan in dit rapport verslag wordt gedaan, heeft de Stichting Bedrijfsfonds Apotheken (SBA) opdracht verleend aan het Researchcentrum voor Onderwijs en Arbeidsmarkt (ROA).

In dit rapport wordt verslag gedaan van een twintigtal gesprekken die in februari en maart 2003 zijn gevoerd met belanghebbenden. In de bijlage van het rapport treft u een lijst aan met de namen van de in het kader van deze verkenning gesproken personen. In de gesprekken zijn de rapporten en de bevindingen uit de eerste cyclus geëvalueerd en is vooral ook aandacht besteed aan actuele onderzoeksvragen en nieuwe aandachtspunten voor de tweede cyclus, die in het najaar van 2003 van start zal gaan. Bovendien is in de gesprekken gevraagd naar de frequentie waarmee de verschillende onderzoeken in het kader van de arbeidsmarktmonitor idealiter zouden moeten plaatsvinden.

Behalve aan de gesprekspartners (zie bijlage 1) zijn wij dank verschuldigd aan dhr. J. Sax van der Weijden en de dhr. P. Georgopoulos van de Stichting Bedrijfsfonds Apotheken voor hun inbreng bij de samenstelling van de scoreformulieren en hun commentaar op een eerdere versie van dit rapport. Ook zijn wij dank verschuldigd aan mevr. I. Tebbens voor haar bijdrage in het plannen en coördineren van de gesprekken.

1. - F. Cörvers, B. Diephuis en B. Golsteyn (2002). Het onbenutte arbeidspotentieel van apothekersassistenten voor de openbare apotheek, ROA-R-2002/2, Maastricht.

- A. de Grip, J. Sanders en I. Sieben (2002). Knelpunten op de arbeidsmarkt en personeelsbeleid in de openbare apotheek, ROA-R-2002/11, Maastricht.

- A. de Grip en I. Sieben (2002). Werken in de openbare apotheek, ROA-R-2002/13, Maastricht. J. Sanders, R. de Vries en M. Wolbers (2003). Apothekersassistenten van school naar werk, ROA-R-2003/5, Maastricht.

- A. de Grip, M. Hensen en I. Sieben (2003). De arbeidsmarkt voor apothekersassistenten tot 2010: een toekomstverkenning, ROA-R-2003/6, Maastricht. 



\section{Inleiding}

Met het gereedkomen van het rapport de arbeidsmarkt voor apothekersassistenten tot 2010: een toekomstverkenning is in april 2003 de eerste tweejaarlijkse cyclus van de Arbeidsmarktmonitor Apotheekbranche afgesloten. In deze eerste cyclus is de arbeidsmarkt voor apothekersassistenten vanuit vijf verschillende invalshoeken geanalyseerd met het doel meer inzicht te krijgen in de arbeidsmarktdynamiek en -problematiek binnen de apotheekbranche. Hierbij zijn vier meetinstrumenten gebruikt.

- Onderzoek onder apothekers

- Onderzoek onder werkende apothekersassistenten

- Onderzoek onder schoolverlaters

- Onderzoek onder niet-participerende apothekersassistenten (het onbenutte arbeidspotentieel)

Op basis van deze vier meetinstrumenten is in vijf rapportages uitgebreid verslag gedaan van de verschillende aspecten van het werk van apothekersassistenten en de situatie op de arbeidsmarkt:

- Het onbenutte arbeidspotentieel van apothekersassistenten voor de openbare apotheek (2002)

- Knelpunten op de arbeidsmarkt en het personeelsbeleid in de openbare apotheek (2002)

- Werken in de openbare apotheek (2002)

- Apothekersassistenten van school naar werk (2003)

- De arbeidsmarkt voor apothekersassistenten tot 2010: een toekomstverkenning (2003)

Deze meetinstrumenten zouden, eventueel in gewijzigde vorm, weer terug kunnen komen in de tweede cyclus waaraan in de tweede helft van 2003 zal worden begonnen. Bepalend hiervoor is allereerst de mate waarin mag worden verwacht dat er veranderingen zullen optreden in de indicatoren die in de eerste cyclus zijn gemonitord. Ook is bepalend in welke mate nieuwe aandachtsgebieden voor de branche belangrijk zijn. In beide gevallen staat de informatiebehoefte van de gebruikers van de arbeidsmarktmonitor centraal. Daarom is in de eerste maanden van 2003 de eerste cyclus van de arbeidsmarktmonitor grondig geëvalueerd en besproken met een twintigtal sleutelpersonen (zie bijlage 1). In deze gesprekken stonden de volgende punten centraal:

- Prioritering van thema's uit de eerste cyclus

- Nieuwe thema's of onderzoeksvragen

- Wenselijke frequentie om bepaalde ontwikkelingen te monitoren

- De relatie tussen de arbeidsmarktmonitor en andere periodieke en ad hoc enquêtes met betrekking tot bepaalde aspecten van de arbeidsmarkt en het werk van apothekers assistenten

De sleutelfiguren uit de apotheekbranche hebben allereerst op scoreformulieren aangegeven welk belang zij hechten aan de verschillende aandachtspunten van de arbeidsmarktmonitor. Ook hebben zij kunnen aangeven met welke frequentie zij vinden dat bepaalde informatie 
zou moeten worden geactualiseerd om het gebruiksnut van de gegevens uit de arbeidsmarktmonitor zo groot mogelijk te maken. Van de evaluatie door middel van deze scoreformulieren wordt in hoofdstuk 2 van dit rapport uitgebreid verslag gedaan.

Het is opmerkelijk hoe groot het belang is dat vrijwel alle sleutelpersonen hechten aan de aandachtspunten van de eerste cyclus van de arbeidsmarktmonitor. In de gesprekken die met de sleutelfiguren zijn gevoerd is hier op doorgevraagd. Daarbij is met name ingegaan op specifieke onderzoeksvragen of specifieke wensen ten aanzien van de invulling van de tweede cyclus van de arbeidsmarktmonitor. Op basis van de gesprekken wordt in hoofdstuk 3 van dit rapport een inventarisatie gemaakt van 'nieuwe' aandachtspunten, nieuwe en specifieke doelgroepen en andere verbijzonderingen.

In het vierde hoofdstuk wordt op basis van de resultaten uit de hoofdstukken 2 en 3 een globale opzet gepresenteerd voor de tweede cyclus van de arbeidsmarktmonitor voor de apotheekbranche. Bovendien wordt ingegaan op de aandachtspunten die in de verschillende te gebruiken instrumenten extra nadruk zouden kunnen krijgen.

\section{Relevante aandachtsgebieden}

In dit hoofdstuk wordt ingegaan op de resultaten van een evaluatie-onderzoek onder verschillende belanghebbenden bij de Arbeidsmarktmonitor Apotheekbranche. Daarbij is gebruik gemaakt van scoreformulieren waarop circa twintig sleutelpersonen die direct of indirect betrokken zijn bij de apotheekbranche hebben aangegeven in hoeverre zij belang hechten aan de verschillende aandachtspunten van de arbeidsmarktmonitor. Allereerst komt in paragraaf 2.1 de vraag aan de orde in hoeverre men de groepen waarover in de eerste cyclus van de monitor informatie is verzameld, zou willen blijven monitoren. Vervolgens wordt in de paragrafen 2.2 tot en met 2.6 ingegaan op de vraag welke aandachtspunten in de vijf verschenen rapporten belangrijk zijn voor de informatiebehoefte van de sleutelpersonen en om die reden onderdeel zouden moeten blijven uitmaken van de monitor.

\subsection{Algemeen}

In het algemeen blijken de meeste betrokkenen veel waarde te hechten aan het voortzetten van de verschillende onderdelen van de eerste cyclus van de arbeidsmarktmonitor. De rapporten die inmiddels zijn verschenen bevatten volgens het overgrote deel van de sleutelpersonen belangrijke tot zeer belangrijke informatie voor de apotheekbranche.

Tabel 2.1 laat zien dat de keuze voor de groepen die in de verschillende rapporten aandacht hebben gekregen door de gesprekspartners in ruime mate wordt onderschreven. Met name de aandacht voor de apothekersassistenten en in iets mindere mate schoolverlaters vindt men zeer belangrijk. Aandacht voor de knelpunten op de arbeidsmarkt, het personeelsbeleid van de apotheken en de informatie over het 'onbenutte arbeidspotentieel' wordt ook door de meeste betrokkenen waarmee is gesproken belangrijk tot zeer belangrijk gevonden. 
Tabel 2.1

Percentage respondenten dat informatie over bepaalde groepen belangrijk vindt $(n=20)$

\begin{tabular}{lrrrrr} 
Informatie over: & $\begin{array}{r}\text { Zeer } \\
\text { belangrijk } \\
\%\end{array}$ & $\begin{array}{r}\text { Belangrijk } \\
\text { Neutraal }\end{array}$ & $\begin{array}{r}\text { Niet zo } \\
\text { belangrijk } \\
\%\end{array}$ & $\begin{array}{r}\text { Onbelang- } \\
\text { rijk } \\
\%\end{array}$ \\
\hline Apothekersassistenten & & $\%$ & & 0 & 0 \\
Apotheken/ werkgever & 64 & 36 & 0 & 0 & 0 \\
Schoolverlaters & 25 & 75 & 0 & 0 & 0 \\
Onbenut arbeidspotentieel & 46 & 46 & 8 & 17 & 0
\end{tabular}

\subsection{Knelpunten op de arbeidsmarkt en personeelsbeleid in de openbare apotheek}

Tabel 2.2 geeft een overzicht van het belang dat er gehecht wordt aan de verschillende aandachtspunten in het werkgeversonderzoek, zoals beschreven in het rapport Knelpunten op de arbeidsmarkt en personeelsbeleid in de openbare apotheek. Het is duidelijk dat vrijwel alle aandachtspunten voor de sleutelpersonen belangrijk tot zeer belangrijk zijn. Enige nadruk wordt gelegd op het belang van het onderscheid dat gemaakt wordt tussen de ketenapotheken en de zelfstandige apotheken. Meer dan $90 \%$ van de gesprekspartners vindt het belichten van de verschillen tussen beide soorten apotheken (zeer) belangrijk. Een aantal respondenten geeft aan het wenselijk te vinden het werken in ketenapotheken nader in beeld te brengen. Datzelfde geldt overigens voor de onder apothekers verzamelde informatie over de aanwezigheid van stagiaires (waaronder voorheen ook BBL'ers) en hun rol in de openbare apotheek. Of stagiaires en BBL'ers een vergoeding krijgen en hoeveel, acht men overigens niet zo van belang. Temeer daar voor de BBL'ers de vergoeding in de nieuwe CAO is vastgelegd.

Andere informatie die minstens $75 \%$ van de respondenten (zeer) belangrijk vindt betreft informatie over:

- Ziekteverzuim

- Vacatures (soort, duur, oorzaak)

- $\quad$ Personeelsopbouw (leeftijd, verblijfsduur, salaris, contractvorm etc.)

- Redenen voor vertrek van assistenten

- Wervingskanalen

- Welke cursussen worden gevolgd en wanneer

- $\quad$ De taken waarop apothekersassistenten worden ingezet

- $\quad$ Effecten van HRM beleid op de productiviteit van de apotheek

Minder belangrijk vindt men informatie over de visie van de apothekers op de mogelijkheden van apothekersassistenten om binnen of buiten de branche een even aantrekkelijke baan te vinden, informatie over de salariëring van apothekersassistenten en informatie over de voorkeur van de apothekers voor een herintreder of een schoolverlater. 


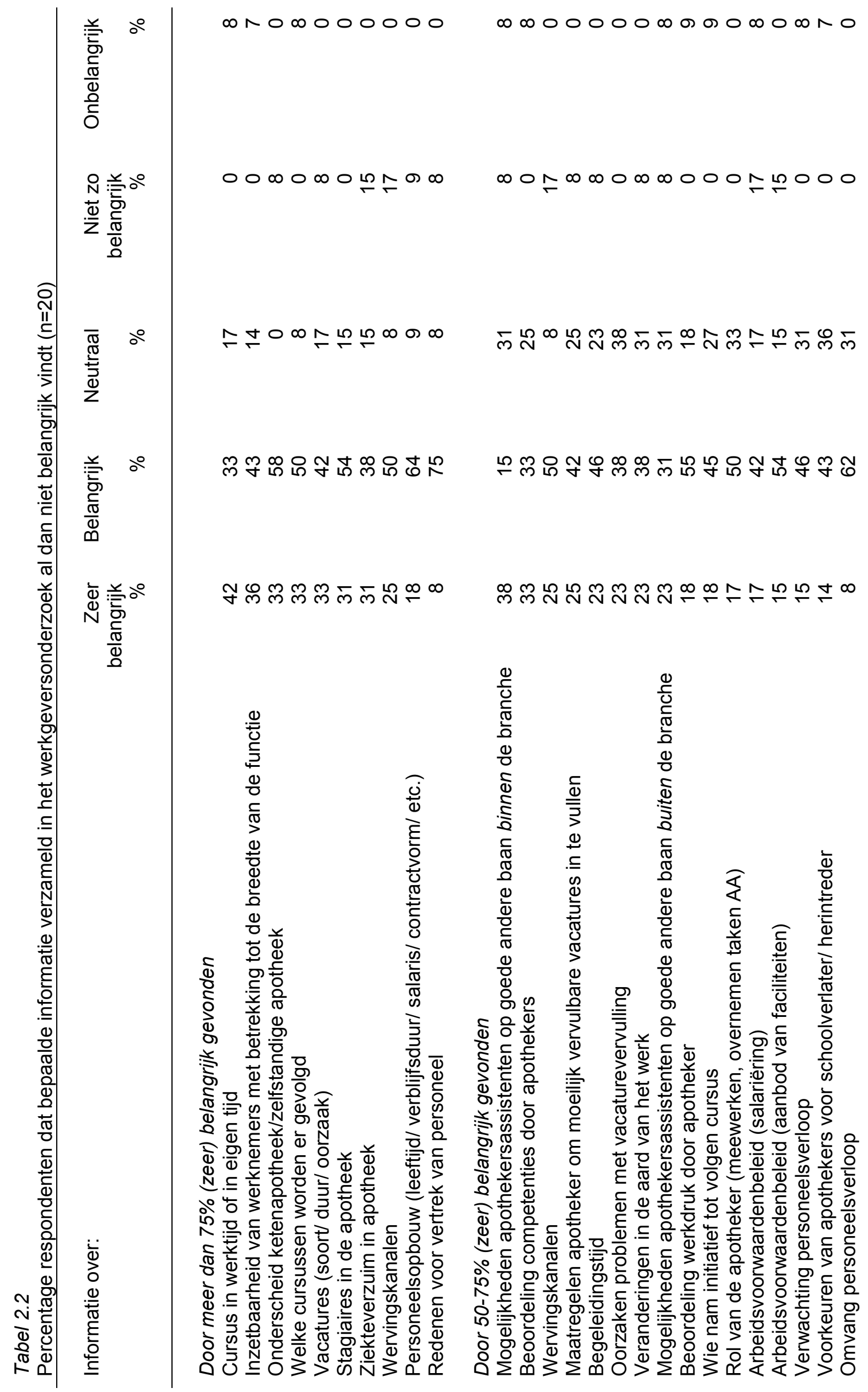




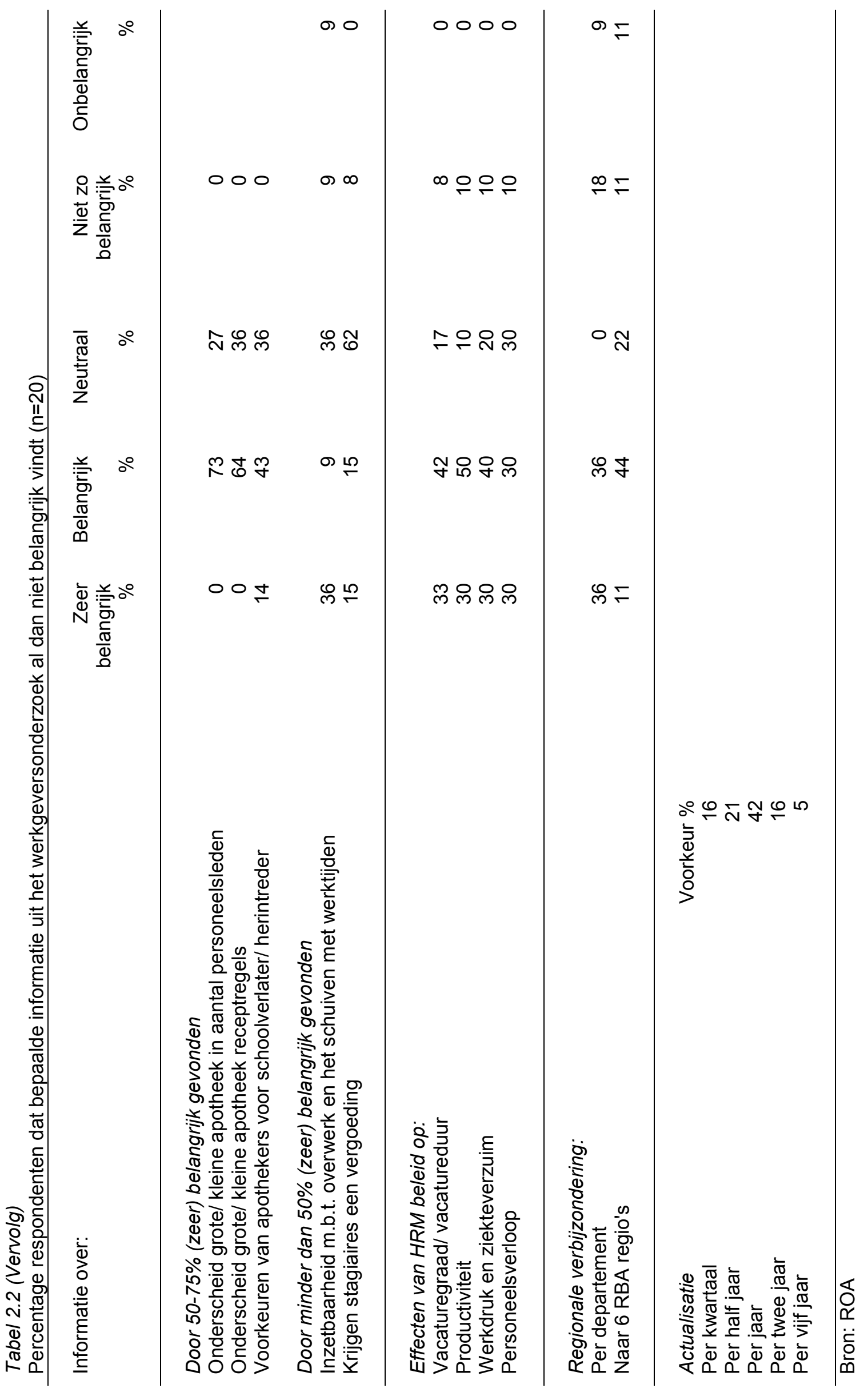


Het minst belangrijk vindt men informatie over de zogenaamde kwantitatieve inzetbaarheid van apothekersassistenten (inzetbaarheid voor overwerk) en de informatie over stagevergoedingen, die ook in de CAO is vastgelegd.

De regionale verbijzondering van de informatie zou bij voorkeur betrekking moeten hebben op de verschillende departementen. Voor meer dan de helft van de respondenten is echter ook de verbijzondering naar zes RBA regio's die in de eerste cyclus van de arbeidsmarktmonitor is gemaakt, van belang.

De informatie die in de enquête onder apothekers wordt verzameld hoeft volgens de meeste gesprekpartners niet vaker dan één keer per jaar te worden geactualiseerd, hoewel er op dit punt wel verschillen zijn tussen de verschillende aandachtspunten van deze enquête. Informatie over ziekteverzuim en vacatures zou met een hogere frequentie (ieder kwartaal) moeten worden geactualiseerd. Informatie over veranderingen in het werk, de perspectieven voor de assistenten, e.d. zou daarentegen met een minder hoge frequentie $(1 \mathrm{x}$ per twee jaar) kunnen worden geactualiseerd.

\subsection{Werken in de openbare apotheek}

Ook het werknemersonderzoek bevat volgens de gesprekspartners nauwelijks onbelangrijke onderwerpen. Wel valt op dat er meer onderwerpen als neutraal worden beoordeeld dan bij de andere instrumenten van de arbeidsmarktmonitor.

Men is vooral geïnteresseerd in wat apothekersassistenten feitelijk doen (hun taken en werkzaamheden). Deze interesse houdt enerzijds verband met het beeld dat men heeft van de toekomstige ontwikkelingen in het werk van de apothekersassistent. Veel sleutelpersonen gaan ervan uit dat er de komende jaren het een en ander in het werk zal gaan veranderen. Zo is er al enige tijd discussie over de mate waarin binnen de apotheek door assistenten tijd wordt besteed aan de bereiding van medicijnen. Anderzijds is er de vraag in hoeverre taken van apothekersassistenten worden overgenomen door andere medewerkers van de apotheek of de apotheker zelf, en omgekeerd. Bovendien is men zeer benieuwd naar de taken die BBL'ers en BOL stagiaires krijgen toebedeeld in de openbare apotheek. Dit hangt ook samen met de discussie over de inhoud van het curriculum van de BOL en BBL opleidingen. Om een goed beeld te krijgen van wat assistenten (en andere medewerkers) moeten kunnen is informatie over hun taken en werkzaamheden in de openbare apotheek volgens bijna alle gesprekspartners (ruim $80 \%$ ) zeer belangrijk.

Naast het krijgen van inzicht in wat assistenten feitelijk doen, vindt men het ook zeer belangrijk inzicht te hebben in de mate waarin zij plezier hebben in (delen van) het werk en in de mate waarin men tevreden is met de inhoud van het werk. Deze interesse houdt verband met de verwachte veranderingen in het werk van de apothekersassistenten in de openbare apotheek. Zo zal bijvoorbeeld, mede als gevolg van overheidsmaatregelen, de 'verketening' van de apotheekbranche toenemen. Hierdoor doet de 'apotheker op afstand' (één apotheker die meerdere apotheken aanstuurt/ beheert) zijn intrede. Verschillende gesprekspartners zijn 
zeer benieuwd wat de fysieke afwezigheid van de apotheker met de tevredenheid en het werkplezier van de apothekersassistenten zal doen.

Informatie over de taken en werkzaamheden en de tevredenheid en het plezier in het werk acht men overigens ook van belang voor de inhoud van toekomstige wervingscampagnes. Een helder beeld van de taken en werkzaamheden en de leuke en minder leuke kanten van het werk van de apothekersassistenten is voor een goede en realistische informatievoorziening naar scholieren en het onbenut arbeidspotentieel toe van groot belang.

Ook de aan het volgen van cursussen gerelateerde informatie blijken velen erg belangrijk te vinden. Met het oog op de afschaffing van het cursus-accreditatiesysteem is men met name geïnteresseerd in informatie over de mate waarin werknemers bereid zijn cursussen te volgen (opleidingsbereidheid). Ook vindt men informatie over de achterliggende motieven van werknemers om cursussen te volgen belangrijk.

Andere onderwerpen die minstens $75 \%$ van de respondenten belangrijk of zeer belangrijk vinden zijn:

- Werkdruk

- Gebruik van HRM faciliteiten

- Inschatting van het eigen perspectief binnen de branche

- Redenen om de openbare apotheek eventueel te verlaten

- Motieven voor herintreders om weer in de openbare apotheek te gaan werken

- Effecten van scholing en flexibiliteit op tevredenheid en loopbaanperspectief

De wenselijkheid van deze punten wijst er op dat men graag wil dat de arbeidsmarktmonitor met name op het terrein van het 'Human Resource Development' en de werkrelaties wat meer de diepte in gaat.

Minder belangrijk vindt men de informatie over reistijden, werktijden en gewenste werkuren. Deze uitkomst sluit aan bij het belang dat het veld hecht aan informatie over overwerk en het schuiven met de werktijden van apothekersassistenten. Blijkbaar is er op dit moment minder interesse voor informatie over het verbreden van de inzetbereidheid van apothekersassistenten.

Over de frequentie waarmee informatie verzameld zou moeten worden, wordt verschillend gedacht. Dit heeft echter in belangrijke mate te maken met de diversiteit van de gegevens die door de monitor verzameld wordt. Sommige elementen vragen om een actualisatie per kwartaal (bijv. ziekteverzuim en vacatures), andere om een jaarlijkse of tweejaarlijkse actualisatie.

Opvallend is ten slotte dat veel sleutelpersonen graag zouden zien dat de gegevens ook verbijzonderd worden naar departement en niet alleen, zoals nu het geval is, naar RBA 


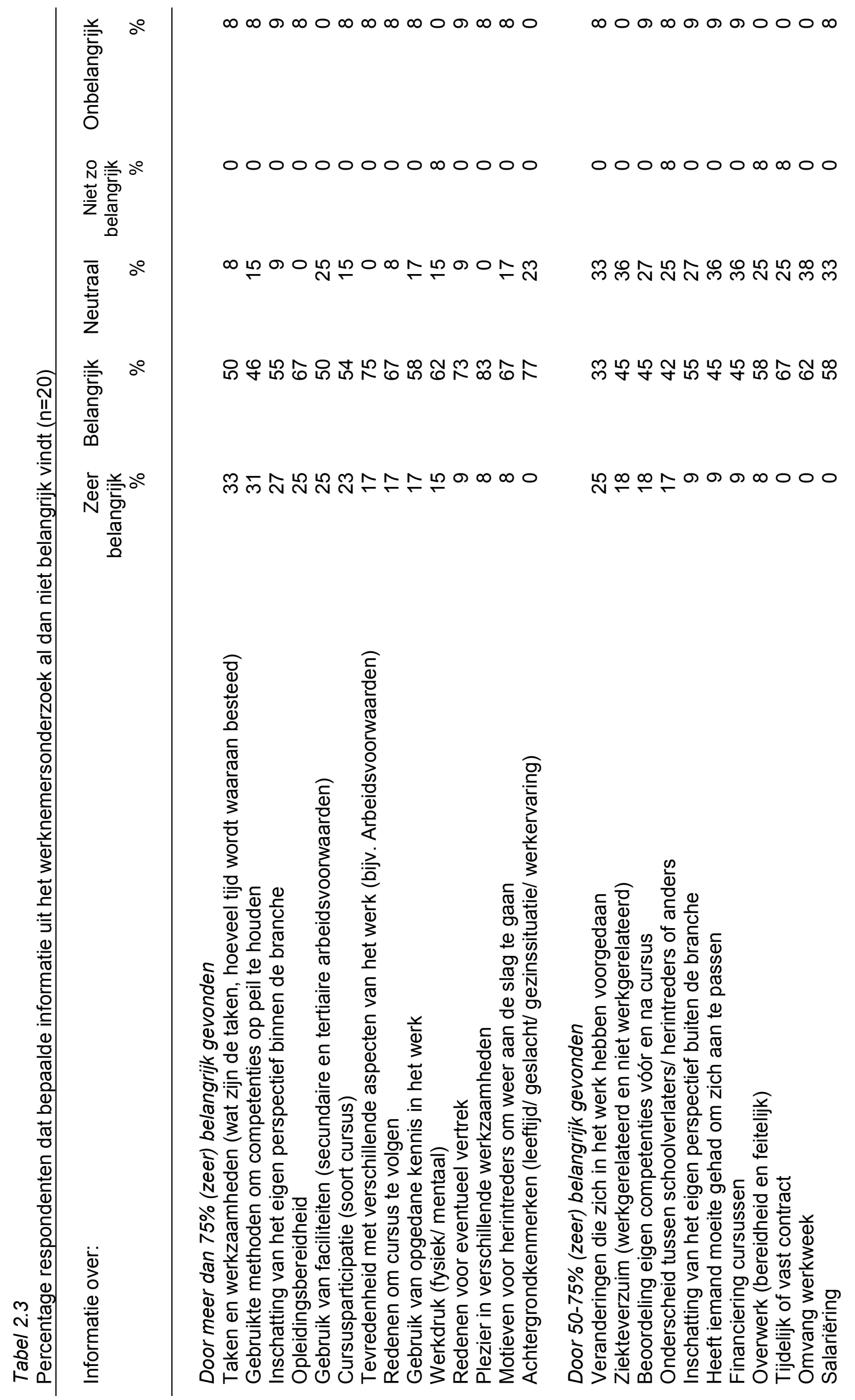




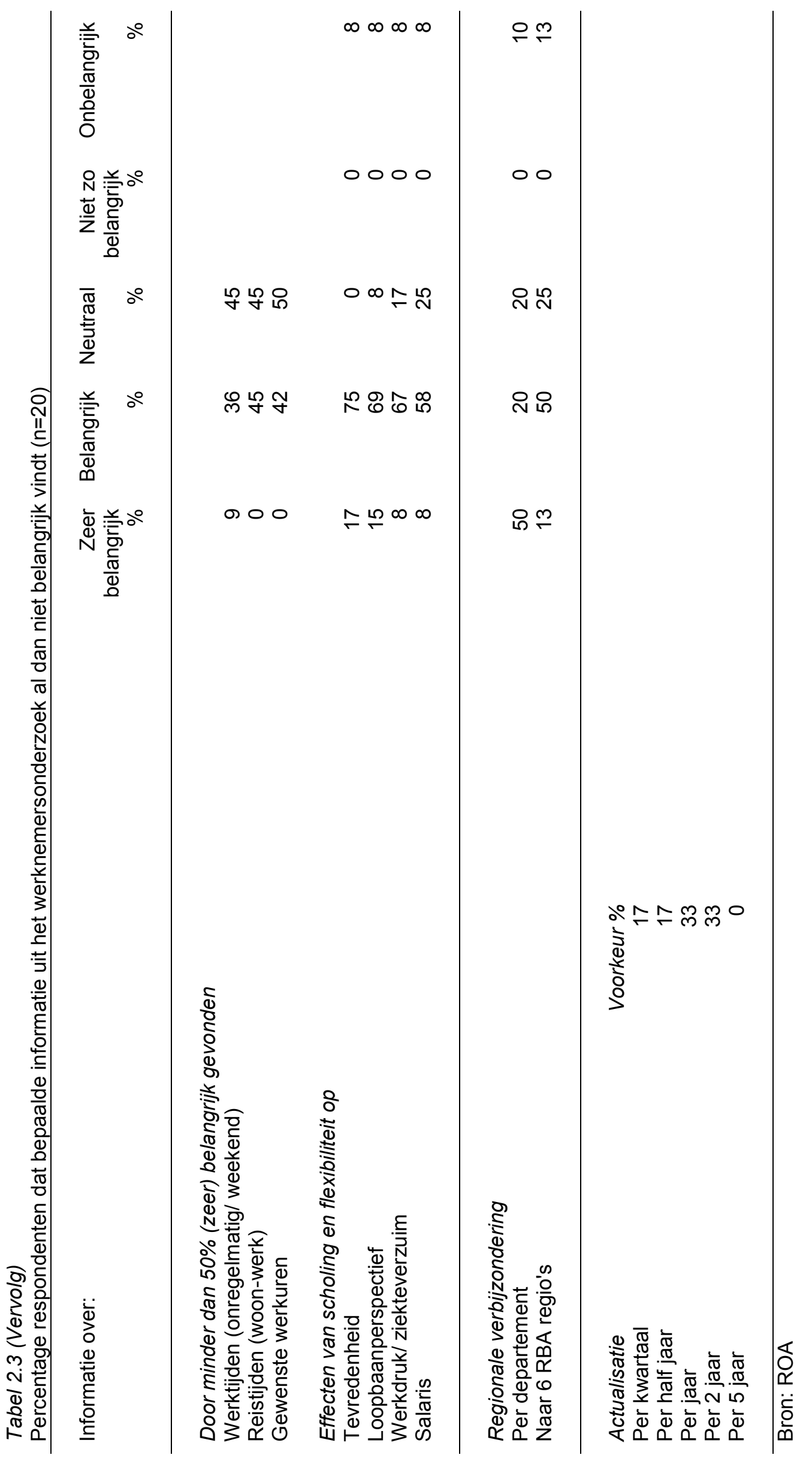


regio. De verbijzondering naar RBA regio wordt overigens nog altijd door $60 \%$ van de respondenten (zeer) belangrijk gevonden.

\subsection{Schoolverlaters}

Tabel 2.4 laat zien dat informatie over de (kwalitatieve) aansluiting van opleiding en beroep voor apothekersassistenten het belangrijkst gevonden wordt. Waarschijnlijk houdt dit verband met eerdere opmerkingen over het belang dat veel sleutelpersonen hechten aan informatie over de feitelijke taken en werkzaamheden van apothekersassistenten vanuit de wens het opleidingscurriculum optimaal te laten aansluiten op de vraag vanuit de markt.

Bijna net zo belangrijk vinden de sleutelpersonen informatie over het aantal leerlingen in de opleiding tot apothekersassistent, het aantal gediplomeerde schoolverlaters (het rendement van de opleiding) en de bestemming van deze gediplomeerde schoolverlaters.

Minder belangrijk vindt men vooral de informatie over intredewerkloosheid, salariëring en de manier waarop de schoolverlater aan de huidige baan is gekomen. Minder dan de helft van de gesprekspartners vindt dit belangrijke informatie. Het minst belangrijk vindt men de vergelijking tussen schoolverlaters die binnen de openbare apotheek zijn gaan werken met assistenten die daarbuiten zijn gaan werken. Dit vindt slechts een kwart van de respondenten belangrijke informatie.

Regionale verbijzonderingen van de informatie over schoolverlaters per departement is voor $60 \%$ van de sleutelpersonen van belang. De verbijzondering naar RBA regio's wordt daarentegen slechts door een minderheid van belang geacht.

Een overgrote meerderheid is van mening dat een jaarlijkse actualisatie van de schoolverlatersinformatie wenselijk is.

\subsection{Onbenut arbeidspotentieel}

De sleutelpersonen geven aan bij de informatie over het onbenutte arbeidspotentieel vooral belang te hechten aan informatie over de redenen waarom iemand destijds gestopt is met werken, informatie over de bereidheid om weer in de openbare apotheek aan de slag te gaan en informatie over belemmeringen bij de terugkeer (tabel 2.5).

Slechts één op de drie sleutelpersonen vindt informatie over het door het onbenutte arbeidspotentieel gewenste loon belangrijk. Ook vindt minder dan de helft van de sleutelpersonen het onderscheid tussen niet-participerenden, werklozen en werkenden van belang.

De regionale verbijzondering in zes RBA regio's wordt door slechts $40 \%$ van de sleutelpersonen belangrijk gevonden, terwijl ruim de helft van de respondenten waarde hecht aan een verbijzondering naar departement. 


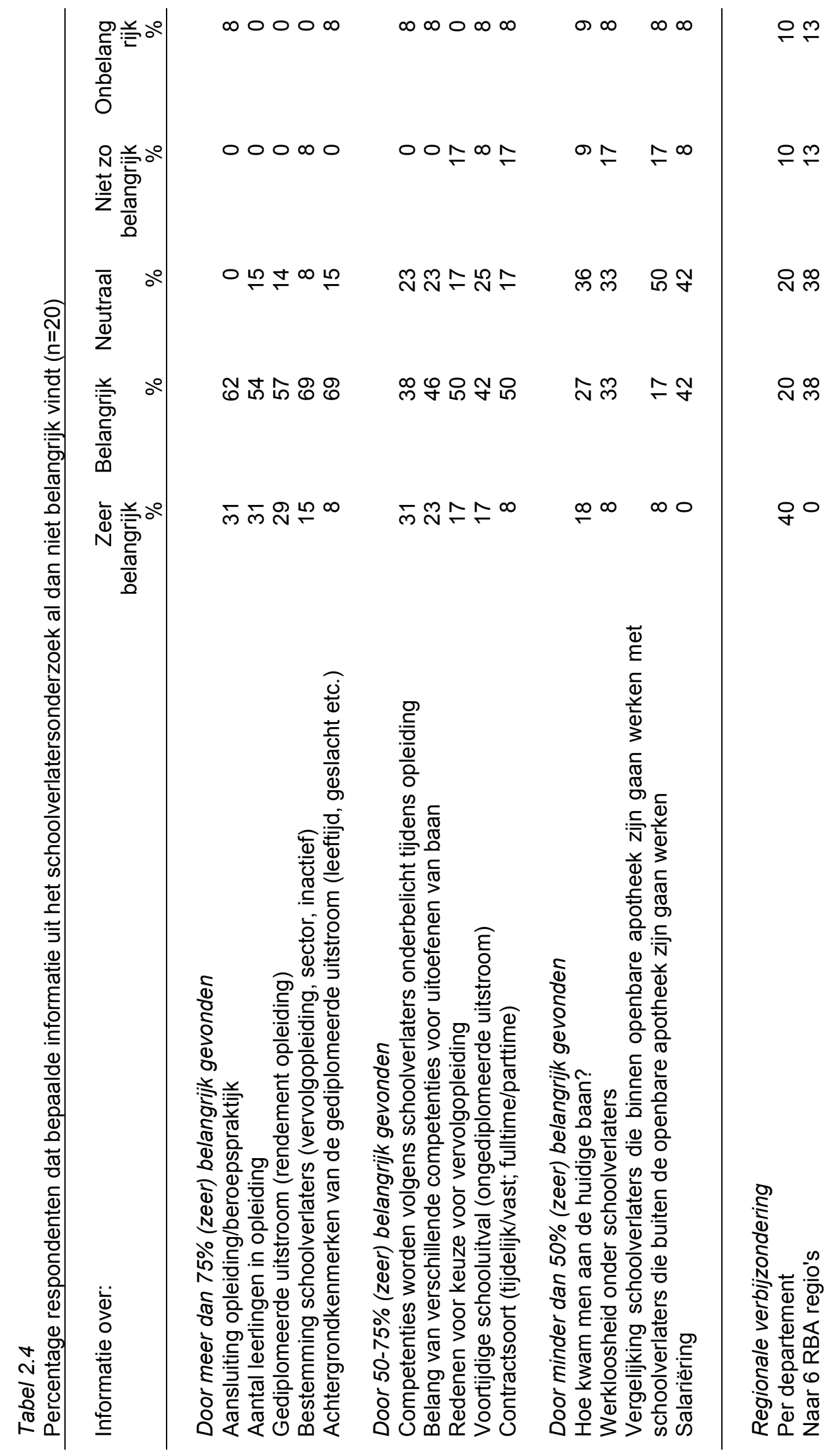




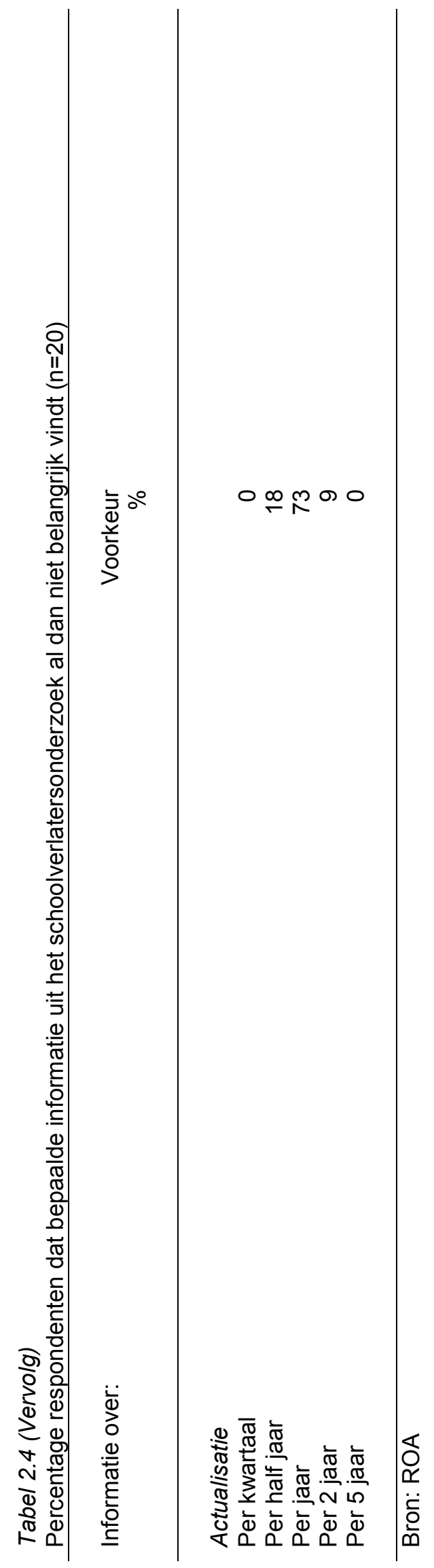


Voor wat betreft de gewenste frequentie van de informatie over het onbenutte arbeidspotentieel voor de apotheekbranche lopen de meningen uiteen. Van de tien sleutelpersonen die op dit punt een voorkeur hebben aangegeven willen er vier een tweejaarlijkse actualisatie en drie een jaarlijkse.

\subsection{Toekomstverkenning}

De toekomstverkenning met betrekking tot de arbeidsmarkt voor apothekersassistenten levert volgens de gesprekspartners de belangrijkste informatie. Uit tabel 2.6 blijkt dat meer dan $80 \%$ van alle respondenten alle elementen uit dit rapport belangrijk of zelfs zeer belangrijk zijn. Informatie over de verwachte korte termijn knelpunten op de arbeidsmarkt (12 jaar) is zelfs voor iedereen (zeer) belangrijk.

Veel respondenten vinden de informatie over de consequenties van overheidsbeleid voor de toekomstige situatie op de arbeidsmarkt ook erg belangrijk. Vooral zicht op de mogelijke consequenties van de bezuinigingsmaatregelen van de minister van WWS voor de arbeidsmarktsituatie vindt men zeer belangrijk.

De regionale verbijzondering van de toekomstverkenning naar RBA regio's vindt men niet zo belangrijk als de verbijzondering naar departement. De meerderheid van de respondenten zou graag willen dat de toekomstverkenning jaarlijks of tweejaarlijks wordt opgesteld.

\section{Doelgroepen en onderzoeksvragen}

In dit hoofdstuk wordt verslag gedaan van de belangrijkste resultaten uit de ruim 20 gesprekken met sleutelpersonen in de apotheekbranche. Het doel van de gesprekken was het verkrijgen van een helder beeld van de precieze behoefte van gebruikers en potentiële gebruikers aan informatie die de arbeidsmarktmonitor beoogt te verzamelen. In de gesprekken is daarom expliciet gevraagd of er onderwerpen, groepen en actuele vraagstukken zijn die volgens de sleutelfiguren (extra) aandacht behoeven.

Uit de gesprekken en de evaluatie blijkt dat vrijwel alle betrokkenen de focus van de arbeidsmarktmonitor zouden willen verbreden. Van belang is vooral informatie over de apotheekhulpen, een groep die in de eerste cyclus nauwelijks aandacht heeft gekregen en informatie over tweede apothekers, die eveneens slechts zeer summier is verzameld. De beste manier om deze en ook andere medewerkers in het onderzoek te betrekken is een verbijzondering naar de 11 functies, die in het nieuwe functiewaarderingssysteem (FUWA) worden onderscheiden. 


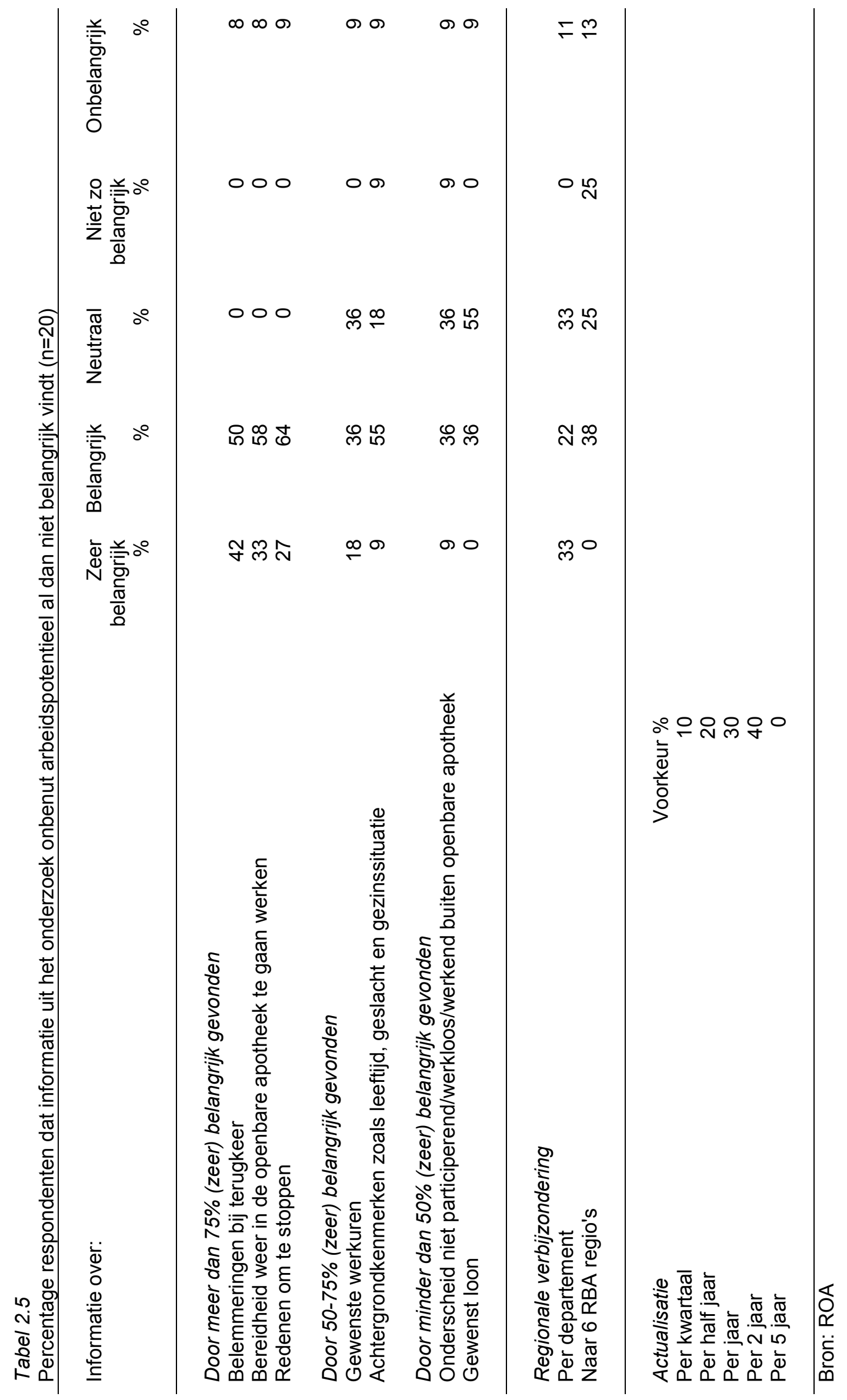




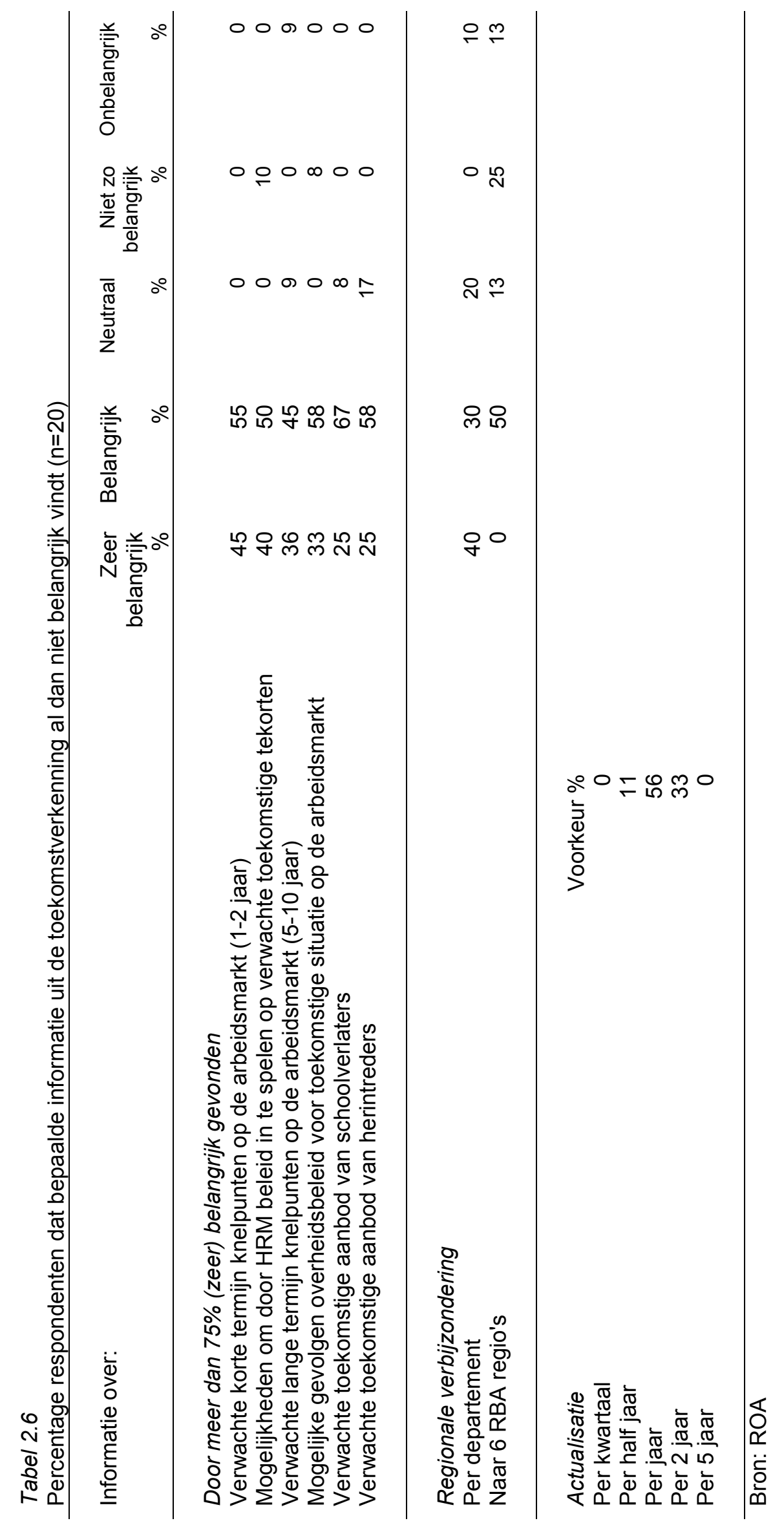


Groepen die in de eerste cyclus van de arbeidsmarktmonitor weinig tot geen specifieke aandacht hebben gekregen, maar die volgens de gesprekspartners wél interessant zijn om in het kader van de monitor apart te benaderen of te behandelen zijn verder:

- $\quad$ BBL'ers en stagiaires

- $\quad$ Scholieren op de voor de apotheekbranche relevante opleidingen

- Voortijdige schoolverlaters

- $\quad$ De werkenden in ketenapotheken

- $\quad$ Apothekers in loondienst (beherend apothekers)

- $\quad$ Assistenten die zijn gaan werken in een ziekenhuisapotheek

- Herintreders

- Allochtonen

- Jonge apothekers

- (Gedeeltelijk) arbeidsongeschikten

De opzet van dit hoofdstuk is verder als volgt. In paragraaf 3.1 worden de hierboven genoemde doelgroepen toegelicht. $\mathrm{Er}$ wordt vooral ingegaan op de redenen die de gesprekspartners hebben om genoemde groepen als doelgroep te bestempelen. In paragraaf 3.2 wordt vervolgens ingegaan op andere aandachtspunten die zijn genoemd door de gesprekspartners. In de meeste gevallen zijn de in paragraaf 3.2 genoemde en besproken aandachtspunten door één of twee van de twintig gesprekspartners genoemd als extra aandachtspunt.

\subsection{Doelgroepen}

BBL'ers

Apothekersassistenten in opleiding vormen voor veel sleutelpersonen een interessante onderzoeksgroep. BBL'ers zullen door de nieuwe FUWA indeling ook via de CAO worden gehonoreerd. Het is voor veel sleutelpersonen van belang te weten welke taken en verantwoordelijkheden BBL'ers feitelijk op zich nemen c.q. opgedragen krijgen en of deze werkzaamheden in het verlengde liggen van hun opleiding.

Bovendien acht men het van groot belang meer zicht te krijgen op de manier waarop de begeleiding van stagiaires plaats heeft. Onduidelijkheid is er vooral over wie de begeleiding nu feitelijk op zich neemt, de apotheker of een ervaren apothekersassistent. Binnen de ROC's worden deze aspecten van de 'beroepspraktijkvorming' tot op heden nauwelijks structureel geëvalueerd.

\section{Scholieren}

Veel vraag is er naar meer informatie over de scholieren die de opleiding tot apothekersassistent volgen. $\mathrm{Er}$ is bijvoorbeeld veel interesse in de overwegingen van scholieren om te kiezen voor de apothekersassistentenopleiding. Dit onder andere om te kunnen beoordelen in hoeverre wervingscampagnes van bijvoorbeeld de SBA effect hebben gesorteerd. Hierbij is extra aandacht gewenst voor de positie van allochtone scholieren en de manier waarop zij leerstof tot zich nemen. 
Eveneens bestaat er behoefte aan inzicht in de stromen tussen de verschillende assistentenopleidingen (tandarts-, dokters- en apothekersassistent). Enkele gesprekspartners uiten de zorg dat leerlingen van de apothekersassistentenopleiding steeds vaker zouden overstappen naar de andere assistentenopleidingen. Als dat zo is, dan zou men graag willen weten over welke aantallen het gaat en waarom leerlingen voor een dergelijke overstap kiezen. Bovendien vindt men informatie over de andere assistentenopleidingen interessant als referentiekader.

Een aantal gesprekspartners geeft aan geïnteresseerd te zijn in informatie over leerlingen op het VMBO en andere mogelijke vooropleidingen. Van deze groep leerlingen wil men graag informatie over de bekendheid en het imago van het werken in de (openbare) apotheek. Deze informatie kan bijzonder nuttig zijn bij het opzetten van wervingscampagnes of het organiseren van open dagen in apotheken of bijvoorbeeld bij ROC's die de opleiding tot apothekersassistent aanbieden. Enige aarzeling is er overigens over de vraag in hoeverre dit soort informatie in een arbeidsmarktmonitor thuishoort.

Diezelfde aarzeling is er als het gaat om de behoefte aan inzicht in specifieke opleidingseisen vanuit ziekenhuisapotheken. De ROC's zijn hier erg in geïnteresseerd. Omdat de arbeidsmarktmonitor vooralsnog primair betrekking heeft op de openbare apotheek, lijkt het verzamelen van deze informatie echter niet binnen de doelstelling van de monitor te passen.

Ook de studenten van de HBO opleidingen 'Farmakunde' of 'Management in de farmaceutische sector' moeten volgens velen tijdens hun studie en in het begin van de loopbaan gevolgd worden. Niet alleen om het rendement van deze opleidingen te kunnen bepalen maar bijvoorbeeld ook om zicht te krijgen op de aansluiting van de opleidingen op de arbeidsmarkt. Bovendien zijn verschillende sleutelpersonen benieuwd naar het effect dat het opzetten van deze HBO opleidingen heeft op de doorstroom van gediplomeerde apothekersassistenten. Gaan zij nu vaker doorstuderen en zo ja, kiezen zij dan bij voorkeur voor de opleiding tot farmakundige, de opleiding tot farmaceutisch manager of toch voor een andere opleiding? Kortom; is men er met het opzetten van de beide HBO opleidingen in geslaagd leerlingen dusdanig meer perspectief te bieden dat zij vaker kiezen voor een (vervolg)opleiding? En, is er überhaupt voldoende vraag naar de competenties van de farmakundige en de farmaceutisch managers binnen de apotheken om de opleiding succesvol te laten zijn?

Ten slotte gaan er stemmen op om meer informatie te verzamelen over de behoefte aan en de inhoud van een officiële opleiding voor apotheekhulpen.

\section{Voortijdige schooluitval}

$\mathrm{Er}$ is een duidelijke behoefte aan informatie over de voortijdige schooluitval. Met name de bestemming van deze voortijdig en ongediplomeerde schoolverlaters en de reden van uitval wordt zeer belangrijk gevonden. Daarbij zou er extra aandacht mogen uitgaan naar de 
voortijdige schooluitval van allochtone scholieren, die als gevolg van de thuissituatie niet goed in staat blijken de relatief zware opleiding af te maken.

\section{Ketenapotheken: de apotheker als werknemer}

Een doelgroep van een geheel andere orde zijn de werkenden in de ketenapotheken. Het volgen van deze categorie apotheken is volgens elke gesprekspartner van groot belang, hoewel de meningen over het hoe en wat wel enigszins uiteen lopen. De ketenapotheken zelf zijn erg enthousiast over de voorgenomen maatregel van VWS om de vereiste dat in elke apotheek tenminste één apotheker aanwezig is te laten vallen. Zelfstandige apothekers zijn daar heel wat minder enthousiast over en de KNMP en de VJA zijn zelfs ernstig bezorgd over de consequenties van een dergelijke maatregel. Reden genoeg om middels de arbeidsmarktmonitor in ieder geval informatie te verzamelen over de ontwikkelingen in de ketenapotheken, waar men ernaar streeft bijvoorbeeld één apotheker op 5 à 6 apotheken te zetten en de informatie over de ketenapotheken te vergelijken met ontwikkelingen in de zelfstandige apotheken.

Aspecten die in dit kader gemonitord zouden moeten worden, zijn bijvoorbeeld de visie van de medewerkers van de apotheek op de fysieke absentie van een apotheker, de werknemerstevredenheid en de gevoelens van werkzekerheid bij de medewerkers, maar bijvoorbeeld ook de visie van de apothekers binnen ketens op hun eigen rol. Hoe ervaren deze beherende apothekers hun rol als werknemer en hoe gaan zij om met de verminderde vrijheid en de verminderde flexibiliteit? Hoe worden assistenten en jonge apothekers begeleid, wanneer er geen sprake meer is van één apotheker per apotheek? Daarnaast is men erg nieuwsgierig naar bijvoorbeeld de reactie van de klant en de huisarts op de fysieke afwezigheid van de apotheker.

Vanuit de ketenapotheken komt ook de vraag in hoeverre volstaan kan worden met een verbijzondering naar ketenapotheken en zelfstandige apotheken, zoals die in de eerste cyclus is toegepast. Men vraagt zich af of het niet beter zou zijn ketenapotheken en in het bijzonder de apothekers die in loondienst werken apart te bevragen. Een van de elementen die daarbij bijvoorbeeld van belang zouden kunnen zijn, zijn de effecten van prestatiebeloning op het niveau van de apotheekteams. Met name voor de ketens is de visie van assistenten en andere apotheekmedewerkers op het instrument van teamprestatiebeloning van belang. De apotheekteams in de ketenapotheken waar de apotheker op afstand opereert, moeten relatief zelfstandig (zonder directe dagelijkse aansturing) gaan werken. Dat vergt het een en ander aan aanpassing van de assistenten. Informatie over wat deze aanpassingen zijn en wat ze betekenen voor de assistenten zelf, voor hun verantwoordelijkheden en voor hun taken is van groot belang.

\section{Ziekenhuisapotheken}

De arbeidsmarktmonitor richt zich vooralsnog uitsluitend op de openbare apotheek. Verschillende sleutelpersonen zijn echter geïnteresseerd in de eventuele verschillen tussen het werken in openbare apotheken en ziekenhuisapotheken. Een van de redenen hiervoor is de verwachting dat het takenpakket van de apothekersassistenten in de ziekenhuisapotheken 
en dat van de apothekersassistenten in de openbare apotheek onder andere door de verschuiving van de zorg van ziekenhuizen naar de thuiszorg of verzorgingstehuizen steeds meer van elkaar zal gaan verschillen. Zo verwacht een aantal betrokkenen dat ziekenhuisapotheken zich meer zullen gaan toeleggen op de bereiding van geneesmiddelen, terwijl openbare apotheken veel van de levering van medicijnen van de ziekenhuisapotheken over zullen nemen.

Anderen verwachten weer dat, als gevolg van de wijzigingen in de regelgeving in 2000 , die het mogelijk maken voor ziekenhuisapotheken om behalve intramuraal ook extramuraal medicijnen te gaan verstrekken, ziekenhuisapotheken zich meer met het uitreiken van medicijnen aan bijvoorbeeld verzorgingstehuizen gaan bezighouden. Om deze en andere vooronderstellingen en verwachtingen te kunnen toetsen is het vanzelfsprekend van belang dat ook gegevens worden verzameld over ziekenhuisapotheken, de apothekersassistenten die daar werkzaam zijn en bijvoorbeeld de taken en werkzaamheden die deze assistenten verrichten.

\section{Herintreders}

Verschillende sleutelpersonen willen graag meer informatie over de herintreders. Waarom zijn zij weer in dienst gekomen en wat doen zij nu feitelijk? Over welke competenties beschikken de herintreders onvoldoende en in hoeverre is er behoefte aan bijscholing op specifieke gebieden?

De ervaringen met herintreders leren dat zij met name op hun plek zijn achter de balie. Zij blijken sociaal en communicatief over het algemeen erg sterk. Daarentegen valt er waarschijnlijk op vakinhoudelijk terrein en vooral op het gebied van het omgaan met computers nog het een en ander te verbeteren. Dat is ook de reden dat een aantal ROC's speciale herintrederscursussen aanbiedt in de vorm van maatwerkopleidingen waarin genoemde aspecten wat meer aandacht krijgen.

Het dreigende tekort aan apothekersassistenten is voor het bestuur van het Departement Limburg aanleiding geweest te zoeken naar mogelijkheden om herintreders in te schakelen. Uit onderzoek van dit departement is destijds gebleken dat in Nederland veel mensen rondlopen met een apothekersassistentenopleiding die niet als apothekersassistent werken. Dat gaf aanleiding een stichting in het leven te roepen (Stichting POOL: Personele Ondersteuning Op Locatie). Deze stichting is feitelijk een pool van in beginsel 30 kandidaten die op aanvraag van een apotheker functies invult die tijdelijk vacant zijn door bijvoorbeeld ziekte of zwangerschap. Een enquête onder apothekers wekt de indruk dat POOL een redelijke kans van slagen heeft. Vanuit dezelfde stichting is in samenspraak met ROC's ook een studieplan opgezet, zodat potentiële herintreders kunnen worden bijgeschoold op een manier die goed past bij de wensen van de herintreder (er is bijvoorbeeld een relatief grote component thuisstudie). Ook hierbij is dus sprake van vergaand maatwerk.

Om herintrederscursussen optimaal in te richten wil men echter meer inzicht in de taken en werkzaamheden waarvoor herintreders tot nu toe worden ingezet én in de opleidingsbehoef- 
te van apothekers voor deze categorie werknemers. Ook wil men meer zicht op het rendement van de herintrederscursussen. In hoeverre volstaat een dergelijke bijscholing en blijven de herintreders ook daadwerkelijk aan de slag of treden zij na een korte periode toch weer uit? Ook is het van groot belang dat van de potentiële herintreders meer bekend is over de belemmeringen die zij voelen om opnieuw aan de slag te gaan. Zo is er misschien een groep potentiële herintreders die het niet ziet zitten om een of meer jaar in de schoolbanken te gaan zitten om zich te laten bijscholen. Die groep is nu niet te onderscheiden, maar wel zeer interessant omdat door middel van maatwerk mogelijkheden bestaan om hen in te zetten.

\section{Allochtonen}

Uit de eerste cyclus van de arbeidsmarktmonitor blijkt dat allochtone apothekersassistenten aan het begin van hun loopbaan wat meer moeite hebben met schrijf- en spreekvaardigheid (Nederlands) dan autochtone assistenten. Omdat de opleiding tot apothekersassistent bijzonder populair is onder allochtonen en apothekers met wie gesproken is erg tevreden zijn over de inzet en nauwkeurigheid van de allochtone assistenten vormt deze aandachtsgroep een van de belangrijkste groepen om in de monitor te volgen.

Belangrijker nog dan het koesteren (en dus monitoren) van de populariteit van de opleiding onder allochtonen vindt men het echter om de allochtonen op de opleiding goed en gericht te begeleiden om daarmee te voorkomen dat zij de opleiding voortijdig staken. Met name in de Randstad wordt zorg uitgesproken over het percentage allochtonen dat de opleiding in het eerste jaar al verlaat. Als oorzaken voor die vroegtijdige schooluitval wordt gewezen op het veelal ontbreken van studiefaciliteiten bij allochtone leerlingen thuis, waardoor bijvoorbeeld de ruimte ontbreekt om huiswerk te maken. Ook zouden allochtone scholieren worden geacht thuis meer mee te draaien in het huishouden, waardoor niet alleen de ruimte maar ook de tijd om te studeren ontbreekt. Omdat de opleiding tot apothekersassistent vrij complex en relatief zwaar is leidt dit waarschijnlijk tot achterstand en voortijdige uitval.

Omdat empirische ondersteuning van deze assumpties ontbreekt en in de eerste cyclus alleen in het schoolverlatersonderzoek aandacht is besteed aan allochtonen, acht men het zinvol in de tweede cyclus bijzondere aandacht te besteden aan allochtonen. Zeker in het onderzoek onder scholieren op de opleiding tot apothekersassistent kan dat tot belangrijke inzichten leiden.

Ook vraagt men zich af of er verschillen zijn voor wat betreft het functioneren van apotheekteams met en apotheekteams zonder allochtonen.

Ten slotte bestaat interesse in de mate waarin allochtone apothekersassistenten worden ingezet vanwege hun competentie om allochtone klanten in de eigen taal te woord te staan. Omdat allochtonen relatief veel medicijnen gebruiken vormen zij een belangrijk onderdeel van de cliëntèle en het is de vraag of deze groep beter kan worden bediend door goed opgeleide allochtonen achter de balie te zetten. Antwoorden op dergelijke vragen kunnen alleen worden gegeven wanneer meer informatie over allochtone werknemers wordt verzameld. 


\section{Jonge apothekers}

Als gevolg van de plannen van De Geus dreigen vooral jonge, startende apothekers in de problemen te komen. Jonge apothekers zijn vaak niet in staat om voldoende financiële middelen te genereren om een apotheek en de daarbij horende goodwill, over te nemen. Dat terwijl zo'n $60 \%$ van de jonge apothekers graag voor zichzelf zou willen beginnen. Medicijngroothandels als OPG en Brocacef bieden vervolgens uitkomst, doordat zij apotheken opkopen en deze onder gunstige voorwaarden doorverkopen aan startende apothekers. Nadeel van deze constructies is echter in veel gevallen dat de startende apotheker gehouden is producten van diezelfde groothandel af te nemen, waardoor een optimaal inkoopbeleid in veel gevallen niet mogelijk is. Daar apothekers voor hun winst grotendeels afhankelijk zijn van de voordelen die zij halen bij de inkoop, komen vooral jonge apothekers in de problemen.

Mede om die reden acht men het van belang dat de opinie van jonge apothekers duidelijker naar voren komt. Wat vinden jonge apothekers nu bijvoorbeeld van de begeleiding die zij hebben gekregen bij hun loopbaanstart? Hoe gaan de jonge apothekers om met HRM beleid? En wat heeft dat laatste voor effect op het personeel?

Voor de tweede cyclus van de arbeidsmarktmonitor zou het mogelijk moeten zijn om een onderscheid te kunnen maken tussen de mening van 'jonge' apothekers en andere apothekers. Bovendien acht men het zinvol een onderscheid te kunnen maken naar 'jonge' en 'oude' apotheken. Dat wil zeggen: een onderscheid tussen apotheken waar een jonge apotheker aan het hoofd staat en apotheken waar een wat oudere apotheker aan het hoofd staat. Enkele van de geïnterviewde sleutelpersonen verwachten dat jonge apothekers anders omgaan met de werving en selectie en de opleiding van hun personeel, maar ook met hun klanten en met huisartsen. Daarbij is het niet alleen van belang te onderzoeken of deze verschillen inderdaad bestaan, maar ook om te onderzoeken of deze verschillen invloed hebben op de klanttevredenheid, de werknemerstevredenheid of bijvoorbeeld de productiviteit van een apotheek.

\section{Gedeeltelijk arbeidsongeschikten}

De aandacht voor gedeeltelijk arbeidsongeschikten is in de eerste cyclus tot een minimum beperkt gebleven. Alleen in het apothekersrapport is enige aandacht besteed aan bijvoorbeeld Risico Inventarisatie en Evaluatie onderzoek en de toepassing van de ARBO wetgeving, maar meer specifieke vragen over bijvoorbeeld de mate waarin gedeeltelijk arbeidsongeschikten worden benaderd bij de werving, de mate waarin gedeeltelijk arbeidsongeschikten werkzaam zijn in de openbare apotheek en welke werkzaamheden zij verrichten ontbreken. Gesprekken met onder andere Maetis ARBO en Remedium maken echter duidelijk dat gedeeltelijk arbeidsongeschikten een belangrijke groep potentiële werknemers zijn en dat het, met bijvoorbeeld de aangescherpte richtlijnen in het kader van de Wet Verbetering Poortwachter in het achterhoofd, zeker de moeite loont meer en gerichte aandacht te hebben voor allereerst het voorkomen van gedeeltelijke arbeidsongeschiktheid, maar daarnaast ook voor de reïntegratie van gedeeltelijk arbeidsongeschikten. 
Door middel van Quickscans brengt Maetis ARBO een breed spectrum van mogelijke klachten in beeld, variërend van agressie en onveiligheid tot hygiëne en bijvoorbeeld beeldschermwerk. Ook wordt informatie verzameld over de aanpassingen in de werksituatie, de regelmogelijkheden van individuen, de manier van leidinggeven en bijvoorbeeld de emotionele belasting. De risico's en prevalentie van belastende arbeidsomstandigheden komen dus goed in beeld, maar succesvolle reïntegraties, aanpassingen aan werkplekken om gedeeltelijk arbeidsongeschikten te laten (her)intreden en meer kwantitatieve cijfers over hoeveel gedeeltelijk arbeidsongeschikten er nu daadwerkelijk zijn, wat zij nog zouden kunnen en wat ervoor nodig is om deze groep werknemers weer mee te kunnen laten werken in de openbare apotheek mankeren.

Van de kant van de apothekers, ROC's en bijvoorbeeld assistenten is in de gesprekken overigens nauwelijks aandacht voor gedeeltelijk arbeidsongeschikten. Het is dus de vraag in hoeverre de aandacht voor deze groep (voormalig) werknemers door de gehele branche echt belangrijk wordt gevonden. In het licht van de toename van de knelpunten in de personeelsvoorziening, die ROA voor de komende jaren voorspelt, is het echter van belang over zoveel mogelijk categorieën potentiële werknemers, waaronder dus ook de gedeeltelijk arbeids(on)geschikten, informatie te verzamelen.

\subsection{Overige aandachtspunten}

In paragraaf 3.1 is een aantal doelgroepen besproken, waarvan de geïnterviewde sleutelpersonen hebben aangegeven dat zij (meer) aandacht verdienen. In deze paragraaf worden nog een aantal specifieke aandachtspunten besproken, die in de meeste gevallen slechts door één of twee sleutelpersonen werden genoemd. In schema 3.1 wordt een overzicht gegeven van alle genoemde punten, die voor de inrichting van een tweede cyclus zeker het overwegen waard zijn. Deze punten worden één voor één kort toegelicht.

Poolvorming is hiervoor al even aan de orde geweest bij de Herintreders, waar wat meer is verteld over de herintrederspool die men in het Departement Limburg wil opzetten. Poolvorming zou echter niet alleen interessant kunnen zijn in het kader van de reïntegratie van herintreders, ook voor zittend personeel zou een dergelijke pool van apothekersassistenten een goede manier zijn om op korte termijn knelpunten aan te pakken. Zo'n pool zou vooral op locaties waar meerdere apotheken dichtbij elkaar opereren kans van slagen hebben. Om te kunnen inventariseren in hoeverre assistenten en apothekers bereid zijn om in een dergelijke pool van assistenten te participeren zou naar deze bereidheid kunnen worden gevraagd.

Klanttevredenheid komt vaker terug als een goede maatstaf voor het succes van een apotheek. Enkele sleutelpersonen voorspellen bijvoorbeeld een afnemende klanttevredenheid wanneer artikel 19 (ten minste één apotheker per apotheek) wordt afgeschaft en de apotheker op afstand gaat fungeren. Ook wil een aantal sleutelpersonen inzicht in verschillen tussen de tevredenheid van klanten van de traditionele apotheken en bijvoorbeeld de ketenapotheken of de zogenoemde uitdeelapotheken, waarmee Albert Heijn momenteel proef draait. Ten slotte wordt klanttevredenheid genoemd als een belangrijke motivator voor 
apothekersassistenten. Klanttevredenheid zou dus als kritieke succesfactor in de arbeidsmarktmonitor moeten worden ingebed.

Behalve de relatie met de klant achten sleutelpersonen ook de relatie met huisartsen een belangrijk aandachtspunt. Hoe verloopt de samenwerking? Hoe verloopt de communicatie? Is men tevreden over de manier van samenwerken? Vragen waarop de monitor vooralsnog niet ingaat, maar die wel van belang worden geacht. Datzelfde geldt overigens voor de relatie tussen zorgverzekeraars en de apothekers. Met name over de visie van zorgverzekeraars op 'de apotheker' is tot op heden maar weinig bekend.

De internationalisering van de apotheekbranche heeft eveneens weinig aandacht gekregen. Gezien de verdergaande liberalisering van de markt vraagt dit onderwerp echter wel steeds meer aandacht. Zo zijn er al buitenlandse bedrijven (Bootz) die hebben geprobeerd een plek te veroveren op de Nederlandse markt. Het is volgens enkele sleutelpersonen in het kader van de kwaliteitsbewaking van de dienstverlening belangrijk om de internationalisering goed te volgen. Vanuit de ROC's komt de vraag naar meer informatie over de kwaliteit van assistenten die buiten Nederland zijn opgeleid ten opzichte van in Nederland opgeleide apothekersassistenten. Dergelijke informatie zou overigens niet alleen voor ROC's van belang kunnen zijn bij het vergelijken van curricula of bijvoorbeeld het opzetten van internationale stageprojecten, maar bijvoorbeeld ook voor het oplossen van arbeidsmarktknelpunten door het aantrekken van buitenlandse assistenten, bijvoorbeeld in de grensregio's.

Schema 3.1

Overige aandachtspunten

\begin{tabular}{|c|c|c|c|}
\hline $\begin{array}{l}\text { Poolvorming } \\
\text { assistenten }\end{array}$ & $\begin{array}{l}\text { Tevredenheid met de } \\
\text { nieuwe FUWA }\end{array}$ & $\begin{array}{l}\text { Onderscheid Dorp en } \\
\text { Stad }\end{array}$ & $\begin{array}{l}\text { Bestuurstaken van } \\
\text { assistenten }\end{array}$ \\
\hline Klanttevredenheid & $\begin{array}{l}\text { Competentiegericht } \\
\text { denken }\end{array}$ & $\begin{array}{l}\text { Stromen op arbeidsmarkt } \\
\text { WAO }\end{array}$ & $\begin{array}{l}\text { Farmakundigen en } \\
\text { farmaceutisch } \\
\text { managers }\end{array}$ \\
\hline $\begin{array}{l}\text { Communicatie met } \\
\text { huisartsen }\end{array}$ & EVC trajecten & Autonoom verzuim & $\begin{array}{l}\text { Imago werk in } \\
\text { apotheek bij leerlingen } \\
\text { VMBO }\end{array}$ \\
\hline Zorgverzekeraars & $\begin{array}{l}\text { Herkenbaarheid } \\
\text { genoemde cursussen }\end{array}$ & Zwangerschapsbeleid & POP's \\
\hline Internationalisering & Teamtrainingen & Financiële kengetallen & \\
\hline $\begin{array}{l}\text { Assistent over } \\
\text { apotheker }\end{array}$ & Pestgedrag & $\begin{array}{l}\text { Kwaliteitsplannen/ } \\
\text { certificering }\end{array}$ & \\
\hline
\end{tabular}

De mening van de assistenten over hun apotheker is in het werknemersonderzoek niet onderzocht. Het is echter zeer waarschijnlijk dat assistenten die niet tevreden zijn over de manier waarop zij begeleiding krijgen van de apotheker, ook minder tevreden zijn met hun werk, minder gemotiveerd aan de slag gaan en bijvoorbeeld minder snel geneigd zijn extra 
uren te maken, zich flexibel op te stellen of een extra opleiding of training te doen. Met het afschaffen van artikel 19 wordt de opvatting van assistenten over hun relatie met de apotheker door een aantal sleutelfiguren cruciaal gevonden voor bijvoorbeeld het functioneren van de ketenformule. Het succes van de ketenformule wordt voor een belangrijk deel bepaald door de mate waarin assistenten in staat zijn en vooral ook de wil hebben met een grote mate van zelfstandigheid 'hun' apotheek te runnen, zonder terug te kunnen vallen op een fysiek aanwezige apotheker. Ketenapotheken verwachten in de eerste jaren enige onrust, maar met goede begeleiding en ondersteuning zal die naar verwachting snel afnemen. Interesse is er dan ook voor monitoring op dit punt.

Daarnaast geeft een aantal sleutelpersonen aan veel belang te hechten aan het oordeel van de assistenten over de nieuwe FUWA en meer specifiek de tevredenheid met de indeling van assistenten in die nieuwe FUWA.

Van de opleidingskant komt in het kader van het meer competentiegerichte denken het verzoek in de monitor ook ruimte te reserveren voor vragen over mogelijke EVC trajecten (Erkennen van Verworven Competenties). De op dit moment gehanteerde eindtermen documentatie is volgens sleutelpersonen rigide en niet competentiegericht. Om in de nabije toekomst te kunnen werken met ontwikkelingsprofielen en competentiemanagement, hetgeen in het kader van de nieuwe FUWA door vrijwel het gehele veld wordt voorgestaan, is een cultuuromslag nodig van kwalificatiegericht denken naar competentiegericht denken. Daarbij vormen de 11 referentiefuncties in de nieuwe FUWA en vooral de daarbijbehorende beroepscompetentieprofielen het uitgangspunt.

In de eerste cyclus werd al veel aandacht geschonken aan competenties, maar veel sleutelpersonen herkenden de benamingen van de competenties onvoldoende. Aansluiten bij de 'bekende' competenties uit de beroepscompetentieprofielen, zou de informatie over de competenties veel beter laten aansluiten bij de informatiebehoefte van de betrokkenen. Daarmee kan ook de kritiek dat de in de eerste cyclus genoemde cursussen niet herkenbaar zijn voor assistenten of apothekers worden ondervangen.

Een belangrijke competentie die in de eerste cyclus aan de orde kwam was het werken in teams. Sleutelpersonen onderschrijven het cruciale belang van teamwork binnen apotheken. De aandacht voor het functioneren van het apotheekteam als geheel is echter volgens enkele sleutelpersonen onderbelicht gebleven, zeker gezien het belang ervan. Met het oog op veranderingen die er de komende jaren binnen apotheken zullen plaatsvinden (steeds meer allochtone medewerkers in het team, andere formele verdeling van de verantwoordelijkheden als gevolg van de nieuwe FUWA) acht men het zinvol meer aandacht te besteden aan apotheekteams. Vanuit de opleidingszijde wordt bovendien ook aangegeven dat er aandacht zou moeten komen voor teamtrainingen. Daarbij zou gevraagd kunnen worden naar de mate waarin dergelijke trainingen worden gevolgd en vooral ook wat er het rendement van is. 
Met de aandacht voor het team als geheel, zou ook pestgedrag aandacht moeten krijgen. Onderzoek toont aan dat bijna één op de vijf apothekersassistenten het afgelopen jaar met pestgedrag te maken heeft gehad. Op het punt van de agressie binnen het apotheekteam of agressie van klanten bestaan bovendien aanzienlijke verschillen tussen stadsapotheken en dorpsapotheken. Ook zijn er waarschijnlijk verschillen in de mate waarin assistenten doorleren en verschillen in de mate waarin apotheken met knelpunten in de personeelsvoorziening worden geconfronteerd. In de rapporten van de eerste cyclus van de arbeidsmarktmonitor is nauwelijks aandacht geschonken aan het onderscheid tussen stads- en dorpsapotheken. Sleutelpersonen achten dit onderscheid echter van groot belang.

Veel sleutelpersonen hechten, zoals reeds in hoofdstuk 2 werd aangegeven, veel waarde aan informatie over de stromen op de arbeidsmarkt. Daarbij gaat het om vragen als: Hoeveel leerlingen beginnen aan de opleiding tot apothekersassistent? Hoeveel scholieren verlaten die opleiding met een diploma? Welk deel van die gediplomeerde assistenten stroomt daadwerkelijk in in de openbare apotheek? Waar gaan de voortijdig schoolverlaters naartoe en waar gaan gediplomeerde assistenten naartoe die niet instromen in de openbare apotheek? Maar ook: Waar gaan apothekersassistenten naartoe die na een tijdje gewerkt te hebben in de openbare apotheek uitstromen? Gaan zij elders werken? Waar? Nemen zij zorgtaken op zich? Of gaan zij misschien een opleiding volgen?

Op deze vragen zou de arbeidsmarktmonitor een helder antwoord moeten kunnen geven. Een van de stromen die in de eerste cyclus nog niet belicht zijn, maar die volgens de vertegenwoordigers van Maetis ARBO en Remedium van groot belang is voor een goed arbeidsmarktbeleid, is de vraag naar het aantal werkenden dat de openbare apotheek verlaat en instroomt in de WAO. Deze stroomcijfers zijn vooral ook van belang om het rendement van investeringen in bijvoorbeeld R.I. en E's en Arbobeleid te kunnen bepalen. Alleen gegevens over het aantal werknemers dat uitstroomt naar de WAO is overigens niet voldoende, zo stelt Maetis ARBO. Informatie over diagnoses en klachten is minstens even belangrijk. Dergelijke informatie is echter te specifiek voor een arbeidsmarktmonitor.

Dit laatste aandachtspunt sluit enigszins aan bij de vraag van een van de sleutelpersonen naar meer informatie of in ieder geval aandacht voor het zogenaamde autonome verzuim. Het is onmogelijk om het ziekteverzuim tot nul te beperken. Een apotheker voert een optimaal verzuimbeleid als het verzuim beperkt blijft tot het autonome verzuim, ofwel het verzuim waar de apotheker zelf weinig tot geen invloed op heeft (bijvoorbeeld het verzuim vanwege sportblessures en niet werkgerelateerde ziekte). Wat het autonome verzuimpercentage is, zou via de monitor of via de reeds bestaande quickscans van Maetis ARBO kunnen worden onderzocht.

Ook zou een aantal sleutelpersonen aandacht willen voor de monitorring van het zwangerschapsbeleid binnen de openbare apotheken. Omdat ruim 98\% van de apothekersassistenten vrouw is, is zwangerschapsbeleid volgens velen een belangrijk punt van aandacht binnen het totale HRM beleid. Wat men zou willen weten is vooral hoe apotheken tijdelijk vrijgekomen arbeidsplaatsen invullen. Wordt dat intern opgevangen of misschien 
door middel van uitzendkrachten? In het kader van de poolvorming zou ook gevraagd kunnen worden naar de wens om bij het opvullen van tijdelijke vacatures gebruik te maken van bijvoorbeeld een assistentenpool.

Om onder andere het rendement van specifieke elementen van het binnen de apotheekbranche gevoerde HRM beleid te kunnen bepalen bestaat er behoefte aan meer financiële kengetallen. Vanuit de KNMP en de SFK is sowieso behoefte aan meer zogenaamde 'harde' cijfers om de ontwikkelingen en veranderingen in het werk binnen de apotheek en bijvoorbeeld ook de situatie op de arbeidsmarkt aan te kunnen relateren. Niet alleen financiële kengetallen worden in dat kader genoemd, maar ook productiviteitskengetallen (WTG-voorschriften, geneesmiddelengebruik, receptregels). Deze gegevens zijn niet alleen interessant om het succes van de sector te kunnen bepalen maar staan ook centraal bij het zoeken naar succesvolle beleidsingrepen, of bijvoorbeeld metingen van effecten van het overheidsbeleid en prognoses daaromtrent. Hoewel er zowel in het rapport Knelpunten op de arbeidsmarkt en personeelsbeleid in de openbare apotheek als in het rapport De arbeidsmarkt voor apothekersassistenten tot 2010: een toekomstverkenning, reeds aandacht aan is besteed, zal er gezien de reacties van sleutelpersonen in de tweede cyclus meer aandacht voor deze gegevens moeten komen.

Kwaliteitsplannen en certificering krijgen de laatste jaren in de branche veel aandacht. Een groot aantal apotheken zit op dit moment dan ook in een certificeringstraject. Bovendien wordt verwacht dat de zorgverzekeraars in de toekomst de eis zullen gaan stellen aan apothekers dat zij niet alleen voldoen aan de Nederlandse Apotheeknorm (NAN), maar ook zijn gecertificeerd door de stichting Harmonisatie Kwaliteitsbeoordeling in de Zorgsector (HKZ). Het ligt om deze reden voor de hand dat in de tweede cyclus van de arbeidsmarktmonitor aandacht wordt besteed aan deze certificering, zeker wanneer relaties worden gelegd met andere aspecten van het personeelsbeleid binnen de openbare apotheek. Daarbij kan bijvoorbeeld worden gedacht aan het effect van certificering op klanttevredenheid, werknemerstevredenheid of productiviteit. Ook kan worden beoordeeld welke apotheken nu eigenlijk werken aan certificering en of gecertificeerde apotheken zich onderscheiden door een effectief HRM beleid.

Daarbij komt dat in de nieuwe FUWA de functie apothekersassistent is uitgebreid met drie varianten, waarvan kwaliteitszorg er één is. Men is benieuwd in hoeverre de kwaliteit van de dienstverlening door apotheken door de aanwezigheid van de kwaliteitszorg-assistent positief wordt beïnvloed. Twee andere argumenten die sleutelfiguren geven om meer aandacht te besteden aan kwaliteitszorg in de monitor zijn:

- Het is belangrijk om te monitoren of de afschaffing van artikel 19 (minimaal één apotheker per apotheek) ertoe leidt dat de kwaliteit van de dienstverlening achteruit zal gaan

- De verdergaande liberalisering van de markt zorgt ervoor dat o.a. supermarkten en drogisterijen zich gaan toeleggen op het verstrekken van medicijnen. Ook hierdoor zou de kwaliteit van de dienstverlening van de branche als geheel achteruit kunnen gaan. 
Het feit dat de nieuwe FUWA de apothekersassistenten aanzienlijk meer carrièremogelijkheden biedt zou ook een nadeel kunnen hebben in de zin dat apothekersassistenten niet langer bestuurstaken op zich nemen in regionale of landelijke belangenorganisaties. Volgens één van de sleutelpersonen zou het interessant zijn te kijken naar de mate waarin relatief ambitieuze apothekersassistenten die voorheen bestuurstaken op zich zouden nemen om hun taken en werkzaamheden interessanter te maken nu kiezen voor een opleiding om zich bijvoorbeeld te specialiseren in de farmaceutische patiëntenzorg of de kwaliteitszorg.

In het kader van carrièreperspectief en loopbaanmogelijkheden is ook veel interesse in het succes danwel falen van de inmiddels in Utrecht opgestarte HBO opleiding tot farmakundige. Met name is men benieuwd naar de taken en werkzaamheden van deze 'nieuwe' groep werknemers. Daarnaast is men ook erg geïnteresseerd in de mate waarin gediplomeerde apothekersassistenten in plaats van direct te gaan werken na hun opleiding kiezen voor de nieuwe HBO opleiding tot farmakundige of bijvoorbeeld de (HBO) opleiding tot farmaceutisch manager. Ook is men benieuwd of deze relatief nieuwe opleidingen de aantrekkelijkheid van de opleiding tot apothekersassistenten in enige mate verhoogt. De mogelijkheden om de eerste lichtingen farmakundigen en farmaceutisch managers te volgen door bijvoorbeeld ook gebruik te maken van informatie uit de jaarlijkse HBO Monitor zouden moeten worden verkend.

De mogelijkheid om vanuit de apothekersassistentenopleiding door te stromen naar de HBO opleiding tot farmaceutisch manager of farmakundige, zou volgens enkele sleutelpersonen overigens een bijkomend voordeel hebben in de zin dat naar alle waarschijnlijkheid ook meer mannen de opleiding tot apothekersassistent zullen gaan volgen. Vooralsnog is ruim $98 \%$ van alle apothekersassistenten vrouw, dus aan mannen gaat een grote groep potentiële werknemers op dit moment nog verloren. Wanneer naast het inmiddels al op een concurrerend niveau gebrachte salaris ook meer perspectief kan worden geboden, dan wordt de apotheekbranche voor meer mannen aantrekkelijk, zo verwacht men. Of en in hoeverre dit ook zo is, zal de monitor kunnen uitwijzen. Daarvoor hoeft in principe aan de opzet van de monitor overigens niet veel te veranderen, zij het dat mannen als groep natuurlijk onderscheiden moeten kunnen worden en dat afgestudeerde studenten van de HBO opleidingen tot farmakundige of farmaceutisch manager zullen moeten worden bevraagd.

Het vergoten van de loopbaanperspectieven door middel van de nieuwe FUWA en het opzetten van genoemde HBO opleidingen, zou volgens veel sleutelpersonen een positieve uitwerking moeten hebben op de aantrekkingskracht van de opleiding tot apothekersassistent. Het onderzoeken van deze effecten vereist echter meer informatie over de totale groep potentiële instromers in de opleiding tot apothekersassistent. Daarbij gaat het om informatie over de manier waarop bijvoorbeeld VMBO schoolverlaters een vervolgopleiding kiezen en over welke informatie ze daarbij beschikken. Wat denken zij eigenlijk van de opleiding tot apothekersassistent? Wat weten zij van het vak van apothekersassistent? Om antwoord op deze vragen te krijgen zou onderzoek moeten worden gedaan naar het imago 
van de opleiding tot apothekersassistent en het imago van het vak van apothekersassistent onder leerlingen van relevante vooropleidingen.

Ten slotte is er een toenemende interesse voor het werken met Persoonlijke Ontwikkelingsplannen, de POP's. In feite komt hier de belangstelling voor meer informatie over competentiegericht denken en carrièreplanning samen. Eén van de ROC's geeft zelfs aan al na te denken over alternatieve manieren om een opleiding te beëindigen, waarbij POP's een belangrijke rol krijgen toebedeeld. Omdat POP's tot nu toe maar sporadisch worden ingevuld in de apotheken, is het te vroeg voor diepgaande studies naar het functioneren van dit instrument. De vraag of POP's zijn gemaakt zal echter wel moeten worden gehandhaafd. Men verwacht immers dat op korte termijn, mede als gevolg van de nieuwe FUWA, het POP populairder zal worden.

De eerste cyclus van de arbeidsmarktmonitor bevat alleen de vraag of er gewerkt wordt met POP's. Die aandacht is echter te beperkt. In de tweede cyclus zal ook moeten worden gevraagd naar de inhoud van de POP's: Welke competenties moeten verder worden ontwikkeld? Worden de afspraken die zijn gemaakt, ook daadwerkelijk nagekomen? Zijn apothekersassistenten tevreden met het instrument? Zijn apothekers er tevreden over?

\section{Opzet tweede cyclus}

In dit hoofdstuk wordt een globale opzet van de tweede cyclus Arbeidsmarktmonitor voor de Apotheekbranche gepresenteerd. Op basis van de resultaten uit de hoofdstukken 2 en 3 , wordt een invulling gegeven aan de vijf instrumenten die ook in de eerste cyclus centraal stonden. Het betreft het werkgeversonderzoek, het werknemersonderzoek, het schoolverlatersonderzoek, het onderzoek onder niet-participerende apothekersassistenten (het onbenutte arbeidspotentieel) en de toekomstverkenning.

In de paragrafen 4.1 tot en met 4.5 wordt allereerst ingegaan op de voorgestelde opzet van elk instrument: wat zijn de te onderzoeken doelgroepen, op welke wijze worden zij ondervraagd, wat is de frequentie van ondervraging en op welk moment kan dit het beste plaatsvinden? Daarna worden de aandachtspunten besproken die in de verschillende instrumenten nadruk zouden kunnen krijgen. Paragraaf 4.6 sluit af met de bespreking van een aantal mogelijk nieuwe instrumenten voor de Arbeidsmarktmonitor Apotheekbranche. Ten slotte wordt in paragraaf 4.7 een overzicht gepresenteerd van de verschillende voorgestelde instrumenten.

\subsection{Werkgeversonderzoek}

\section{Opzet}

Het werkgeversonderzoek richt zich in principe op alle 1.630 openbare apotheken in Nederland en heeft als doel informatie te vergaren over apotheken en werkgevers (apothekers). Aan een dergelijk werkgeversonderzoek wordt in de apotheekbranche veel waarde gehecht. Uit hoofdstuk 2 bleek dat alle gesprekspartners informatie over 
apotheken/werkgevers belangrijk vinden. Een kwart van de respondenten vindt deze informatie zelfs zeer belangrijk.

Voorgesteld wordt om, net als in de eerste cyclus, alle apothekers te benaderen met een schriftelijke vragenlijst. Door alle apothekers individueel te benaderen, wordt getracht de deelname van een zo groot mogelijk aantal apothekers aan het onderzoek te bewerkstelligen. In 2001 stuurden 549 apothekers de vragenlijst ingevuld terug. Hierdoor was het mogelijk de uitkomsten van de enquête te verbijzonderen naar zes RBA regio's. Men hecht veel waarde aan deze regionale verbijzondering, al heeft een verbijzondering op departementsniveau de voorkeur. Een dergelijke gedetailleerde uitsplitsing (er zijn ongeveer 20 departementen) is bij het werkgeversonderzoek echter alleen mogelijk wanneer de respons in de apothekersenquête veel hoger uitvalt dan de respons in de eerste cyclus. Dit is niet waarschijnlijk.

De Stichting Farmaceutische Kengetallen (SFK) zou weer verzocht kunnen worden het veldwerk voor dit onderzoek te verrichten. Het voordeel hiervan is dat de SFK een ruime ervaring heeft met het doen van onderzoek in de apotheekbranche. Zij hebben bovendien een goede ingang in het veld, hetgeen de respons ten goede kan komen. In 2001 werd op deze wijze een respons van $42 \%$ behaald. Ook heeft de SFK de mogelijkheid de enquêteresultaten te relateren aan andere informatie die men verzamelt (receptregels). Nadeel is dat de ruim 200 apothekers die niet bij de SFK aangesloten zijn buiten het onderzoek vallen.

Het is belangrijk om ervoor te zorgen dat met name de apotheken die in de eerste cyclus aan het onderzoek hebben deelgenomen, opnieuw meedoen. Door een panel van deelnemende apothekers te creëren, kunnen ontwikkelingen in de tijd goed gevolgd worden. Daarnaast kan er beter inzicht verkregen worden in de effecten van het HRM beleid en kunnen ook andere causale relaties gelegd worden. Immers, door op twee tijdstippen te meten, kunnen oorzaak en gevolg beter uit elkaar gehaald worden. Het is daarom van belang dat de informatie uit de onderzoeken van de eerste en de tweede cyclus aan elkaar gekoppeld kunnen worden. De SFK heeft aan iedere apotheek een apotheeknummer toegekend, dat als een identificerende code gebruikt kan worden. Tevens biedt dit nummer de mogelijkheid om enkele belangrijke kerngegevens aan het bestand te koppelen, zoals het aantal verwerkte receptregels per apotheek.

Volgens de meeste gesprekspartners hoeft de informatie die in de enquête onder apothekers verzameld wordt, niet vaker dan één keer per jaar geactualiseerd te worden. Wel blijkt dat het wenselijk wordt gevonden als bijvoorbeeld informatie over ziekteverzuim en vacatures, vaker verzameld zou worden. Dit zou gerealiseerd kunnen worden door de SFK een deel van de populatie bijvoorbeeld vier keer per jaar met een beperkte vragenlijst te laten benaderen. De informatie die deze aanvullende enquêtes oplevert, zou dan gekoppeld moeten kunnen worden aan de Arbeidsmarktmonitor Apotheekbranche. Hierbij moet wel bedacht worden dat het benaderen van apothekers met een hogere frequentie dan één keer per jaar het grote gevaar met zich meebrengt dat er op een gegeven moment 
enquêtemoeheid optreedt, waardoor ook de bereidheid om aan de jaarlijkse enquête deel te nemen vermindert.

Een aantal gesprekspartners geeft aan dat andere aandachtspunten met een minder hoge frequentie geactualiseerd kunnen worden, bijvoorbeeld één keer per twee jaar. Het gaat dan om informatie over onder andere veranderingen in het werk en de arbeidsmarktperspectieven van apothekersassistenten/werknemers. Bij een jaarlijkse enquête onder apothekers betekent dit dat sommige aandachtspunten het ene jaar in de vragenlijst opgenomen kunnen worden, terwijl andere punten in het daaropvolgende jaar aan de orde komen. Dit biedt de mogelijkheid om de vrijgekomen ruimte (voor een deel) te benutten om actuele zaken te bevragen. Nog belangrijker is dat met deze opzet de jaarlijkse vragenlijst beperkt kan blijven, hetgeen de respons ten goede zal komen.

Uit de gesprekken is verder naar voren gekomen dat er grote belangstelling is voor de rol van apothekers binnen een keten. Deze apothekers zouden dan ook in een aparte module van de enquête aanvullende vragen voorgelegd kunnen krijgen, bijvoorbeeld over de rol van de apotheker als werknemer (beherend apotheker). Dit kan bewerkstelligd worden door een inlegvel aan de apothekersenquête toe te voegen. Wanneer blijkt dat er behoefte bestaat om meer dan een paar aanvullende vragen aan deze ketenapothekers te stellen, dan zou de module kunnen uitgroeien tot een aparte vragenlijst.

We stellen voor om de eerstvolgende enquête onder apothekers in september 2003 te houden en de daaropvolgende enquête in september 2004.

\section{Aandachtspunten}

In tabel 4.1 wordt een overzicht gegeven van de aandachtspunten die in het onderzoek onder apothekers van belang zijn. Tevens wordt hierbij telkens de frequentie van de bevraging aangegeven. De belangrijkste onderwerpen zullen ieder jaar in de enquête kunnen terugkomen. Het gaat in de eerste plaats om een aantal kenmerken van apotheken, zoals het onderscheid in kleine en grote apotheken en de openingstijden. Deze vragen werden ook in de eerste cyclus van de Arbeidsmarktmonitor voor de Apotheekbranche gesteld. Wel zullen de antwoordcategorieën op bepaalde punten moeten worden aangepast. Zo moet het bij het karakteriseren van de apotheek bijvoorbeeld ook mogelijk worden aan te geven of apotheken werken binnen een formule. Ook is het wenselijk om stadsapotheken van dorpsapotheken te kunnen onderscheiden en om na te gaan of er binnen een (keten)apotheek een apotheker fysiek aanwezig is of niet en of de apotheker die verantwoordelijk is voor een apotheek al dan niet in loondienst is. Om te kunnen beoordelen in hoeverre er verschillen bestaan tussen jonge en wat oudere apothekers in hun personeelsbeleid en het succes daarvan, is het ook wenselijk om te vragen naar de leeftijd van de (beherend) apotheker. Daarnaast is het wenselijk om vragen over belangrijke financiële kengetallen (bijvoorbeeld het bedrijfsresultaat van de apotheek) en de HKZ en/of NAN certificering van de apotheek jaarlijks in de vragenlijst op te nemen. 
Verder is het wenselijk om ieder jaar vragen te stellen over de personeelsopbouw in de apotheek. Het gaat dan om zaken als werkervaring, salaris, contractvorm en dergelijke. Hierbij zou een onderscheid gemaakt kunnen worden naar de elf functies die in het nieuwe FUWA voorkomen. Ook de inzetbaarheid van werknemers en de beoordeling van de werkdruk zouden ieder jaar aan de orde kunnen komen, evenals de beoordeling van de competenties van het aanwezige personeel. De kritiek vanuit het veld op de in de eerste cyclus onderscheiden competenties geeft echter wel aanleiding om de competentieset zoals die nu is opgenomen te wijzigen, zodat deze beter aansluit bij het begrippenkader van apothekers en assistenten. Dat betekent overigens dat in andere instrumenten van de arbeidsmarktmonitor dezelfde competentieset zou moeten worden gehanteerd.

Tabel 4.1

Aandachtspunten van het onderzoek onder apothekers/werkgevers en frequentie van bevraging

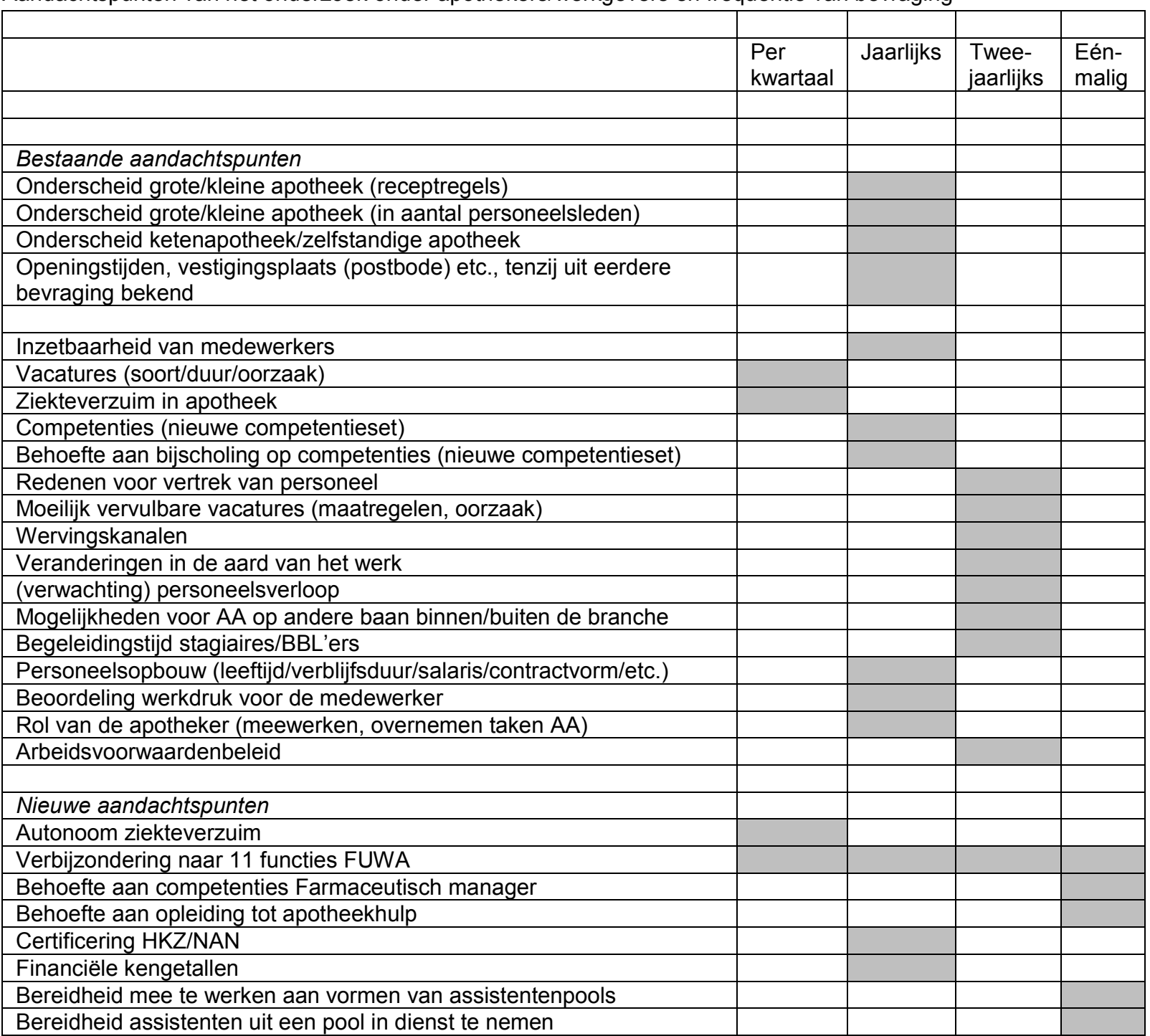

Informatie over cursussen die door assistenten gevolgd worden, kan in principe het beste alleen in de werknemersenquête verzameld worden. In het werkgeversonderzoek zou echter wel gevraagd kunnen worden wat volgens de apotheker de behoefte is aan bijscholing van 
het personeel. In dat kader past ook de vraag in hoeverre behoefte is aan de competenties die farmaceutisch managers en farmakundigen meekrijgen vanuit hun $\mathrm{HBO}$ opleiding en de vraag in hoeverre er van de kant van de apothekers behoefte is aan een officiële opleiding tot apotheekhulp. Deze laatste vragen hoeven echter in principe slechts eenmalig aan bod te komen.

Een aantal onderwerpen hoeft niet jaarlijks, maar tweejaarlijks aan de orde te komen. Het gaat dan om zaken die volgens de sleutelpersonen minder aan verandering onderhevig zijn, zoals informatie over veranderingen in het werk van de apothekersassistenten, aspecten van werving en selectie en het gevoerde personeelsbeleid. Vanwege de recente invoering van de nieuwe FUWA ligt het echter voor de hand om in september 2003 de vragen over veranderingen in het werk van de apothekersassistenten zeker mee te nemen.

De informatie over ziekteverzuim en openstaande vacatures zou daarentegen met een grotere frequentie verzameld kunnen worden. Zoals hierboven al is besproken, zouden dit soort vragen ieder kwartaal via een beknopte enquête door de SFK verzameld kunnen worden, om daarna aan de arbeidsmarktmonitor gekoppeld te worden.

Ten slotte wordt de vorming van assistentenpools als een interessant onderwerp genoemd. In de tweede cyclus zou daarom eenmalig gevraagd kunnen worden of apothekers bereid zouden zijn een rol te vervullen bij de vorming van assistentenpools en of zij zouden willen werken met assistenten uit een dergelijke pool.

\subsection{Werknemersonderzoek}

Opzet

In de eerste cyclus van de Arbeidsmarktmonitor Apotheekbranche zijn in het werknemersonderzoek alleen de apothekersassistenten benaderd. Zij vormen $80 \%$ van de werknemers in de openbare apotheek. Informatie over assistenten wordt door maar liefst $64 \%$ van de gesprekspartners als zeer belangrijk ervaren. Daarnaast blijkt uit de gesprekken dat andere groepen werknemers ook een plaats in de Arbeidsmarktmonitor voor de Apotheekbranche moeten krijgen. Zo hechten bijna alle respondenten veel waarde aan het ondervragen van apotheekhulpen. Meer in het algemeen geldt dat men geïnteresseerd is in een verbijzondering van de informatie naar de elf functies die in de nieuwe FUWA onderscheiden worden. Uitgangspunt in het werknemersonderzoek is dan ook het verzamelen van vergelijkbare informatie over alle elf functies, die vanaf 1 april 2003 in de Nederlandse apotheken bestaan.

Het onderzoek wordt gehouden onder een steekproef van medewerkers die getrokken wordt uit het 'pensioenbestand medewerkers apotheken' van het PMA. In dit bestand wordt een onderscheid gemaakt tussen zogenaamde A-medewerkers en B-medewerkers. Onder de Amedewerkers vallen de gediplomeerde apothekersassistenten, de B-medewerkers zijn alle overige werknemers in de openbare apotheek, met uitzondering van de (tweede) apotheker. Een onderzoek onder tweede apothekers zal in paragraaf 4.6 besproken worden; hier richten we ons op een enquête onder de apothekersassistenten en de overige werknemers. 
Op 1 januari 2002 waren er volgens het PMA zo'n 12.640 apothekersassistenten in dienst. Gezien de omvang van deze groep, kan er - net als in de eerste cyclus - volstaan worden met het ondervragen van een steekproef. Bij het samenstellen van deze steekproef kan in de eerste plaats voorrang gegeven worden aan de 1.324 apothekersassistenten die in de eerste cyclus aangaven opnieuw te willen meewerken. Bureau Intomart heeft de naam en adresgegevens van deze apothekersassistenten bewaard. Door een koppeling te maken tussen de informatie die assistenten in de eerste en in de tweede cyclus gegeven hebben, kunnen ontwikkelingen in de tijd goed gevolgd worden.

Daarnaast is het van belang dat met name assistenten ondervraagd worden die werkzaam zijn bij apotheken die aan het werknemersonderzoek hebben deelgenomen. Het is immers zeer waardevol gebleken om het onderzoek onder apothekersassistenten te relateren aan het onderzoek onder apothekers. Op deze wijze kan onderzocht worden welke korte of lange termijn gevolgen de ontwikkelingen in een apotheek hebben op de bij deze apotheek werkzame apothekersassistenten.

De steekproef onder apothekersassistenten zou ten slotte kunnen worden aangevuld met andere assistenten uit het bestand van het PMA. Net als in de eerste cyclus zou er gestreefd moeten worden naar een steekproefomvang van zo'n 6.000 apothekersassistenten. Bij een vergelijkbare respons als in de eerste cyclus (54\%) kan mogelijk naast de verbijzondering naar 6 RBA regio's ook een regionale verbijzondering op departementsniveau gerealiseerd worden.

Wat de overige medewerkers in de openbare apotheek betreft, is het te overwegen alle Bmedewerkers die bij het PMA ingeschreven staan te benaderen. Op 1 januari 2002 betrof het zo'n 3.600 medewerkers. Ook hier is de koppeling tussen de informatie die medewerkers en hun apothekers geven van groot belang.

Beide groepen (de A-medewerkers en de B-medewerkers) zouden aparte vragenlijsten kunnen ontvangen. De vragen over werkzaamheden, competenties en cursussen en de bijbehorende antwoordcategorieën zullen immers verschillen tussen de twee groepen. Bij de vraagstelling zal echter wel gelet worden op onderlinge consistentie en waar mogelijk zullen dezelfde vragen gehanteerd worden.

Werknemers die in ketenapotheken werkzaam zijn, zouden een aparte module voorgelegd kunnen krijgen met vragen over het werken in een ketenapotheek. Net als bij het onderzoek onder apothekers kan dit in eerste instantie worden gerealiseerd door een inlegvel aan de enquête toe te voegen. Mocht later blijken dat er nog meer aanvullende vragen aan werknemers die in ketenapotheken werken gesteld dienen te worden, dan zou er een aparte vragenlijst voor deze groep werknemers ontwikkeld kunnen worden.

Het onderzoek onder werknemers kan eveneens jaarlijks plaatsvinden. De meeste sleutelfiguren vinden dit een goede frequentie. Net als in het werkgeversonderzoek kunnen sommige onderwerpen echter om de twee jaar bevraagd worden. Dit levert ruimte op voor 
actuele kwesties en beperkt de lengte van de vragenlijst, hetgeen de respons ten goede komt.

De enquêtes onder werknemers kunnen het beste na afloop van het onderzoek onder apothekers gehouden worden. Dit maakt het mogelijk om werknemers die werkzaam zijn in apotheken die aan dit onderzoek meedoen met voorrang te behandelen. Het werknemersonderzoek kan dan ook in november 2003 en november 2004 gepland worden.

\section{Aandachtspunten}

Tabel 4.2 geeft een overzicht van de belangrijkste aandachtspunten voor het werknemersonderzoek en de frequentie waarmee bepaalde onderwerpen in het onderzoek aandacht moeten krijgen. Zoals reeds aangegeven, zullen er aparte vragenlijsten komen voor A- en B-medewerkers in de openbare apotheek, waarbij rekening gehouden wordt met de nieuwe FUWA functiecategorieën. Het onderscheid tussen herintreders en andere apothekersassistenten kan worden gehandhaafd. Aan de herintreders zullen vervolgens additionele vragen worden voorgelegd, bijvoorbeeld over hun ervaring met herintrederscursussen.

De taken en werkzaamheden zoals die in de eerste cyclus zijn gebruikt, zouden waar nodig aangepast kunnen worden aan het Functiehandboek Apotheken. De beschrijving van de taken en werkzaamheden van niet-apothekersassistenten kunnen eveneens uit deze documentatie gehaald worden. Ook zal eenmalig gevraagd worden naar de tevredenheid van medewerkers over hun indeling in de nieuwe FUWA.

Vragen naar taken, werkzaamheden en de veranderingen daarin kunnen in principe tweejaarlijks worden voorgelegd, omdat het de verwachting is dat de antwoorden van jaar tot jaar niet veel zullen veranderen. Datzelfde geldt voor de vragen over bijvoorbeeld de inschatting van de huidige arbeidsmarktpositie, de arbeidsomstandigheden, mogelijkheden voor kinderopvang, overwegingen bij de beslissing om her in te treden, of men naar ander werk zoekt, veranderingen in het werk en de verwachte arbeidsmarktsituatie over 5 jaar. Ook de tevredenheid met aspecten van het personeelsbeleid en de mogelijke vertrekmotieven zullen tweejaarlijks gemeten worden.

Informatie over gevolgde cursussen, de reden waarom bepaalde cursussen gevolgd zijn en de bereidheid van werknemers om opleidingen te volgen, kunnen jaarlijks worden verzameld. Dat geldt ook voor de bereidheid zich breed in te zetten en de inschatting van werknemers van hun eigen competenties en de behoefte aan bijscholing op bepaalde competenties (een nieuw element). Net als in het onderzoek onder apothekers is het nodig de competenties in het werknemersonderzoek aan te passen om te komen tot een voor de betrokkenen herkenbare set competenties. Vanwege het belang dat velen hechten aan de informatie over tevredenheid en plezier in het werk en de werkdruk zullen deze vragen ook jaarlijks worden voorgelegd. 
Een van de nieuwe, in principe eenmalige, elementen in de tweede cyclus kan de vraag zijn in hoeverre werknemers interesse hebben om in een pool (van werknemers) mee te draaien. Andere nieuwe elementen in het onderzoek kunnen de mening van medewerkers over de apotheker en diens aan- of afwezigheid, en hun opvatting over de indeling in de FUWA systematiek zijn. Daarnaast zullen jaarlijks vragen gesteld worden over de deelname van medewerkers aan en opvatting over teamtrainingen, terwijl er tweejaarlijks gevraagd wordt naar ervaringen met pestgedrag en de mate waarin medewerkers bestuurstaken verrichten. Speciale aandacht krijgt ook het Persoonlijke Ontwikkelingsplan. Niet alleen het bestaan ervan wordt jaarlijks gemeten, maar ook of er concrete afspraken gemaakt worden en in hoeverre deze afspraken worden nagekomen. Ook willen we weten in hoeverre werknemers dit instrument waarderen.

Tabel 4.2

Aandachtspunten van het onderzoek onder werknemers en frequentie van bevraging

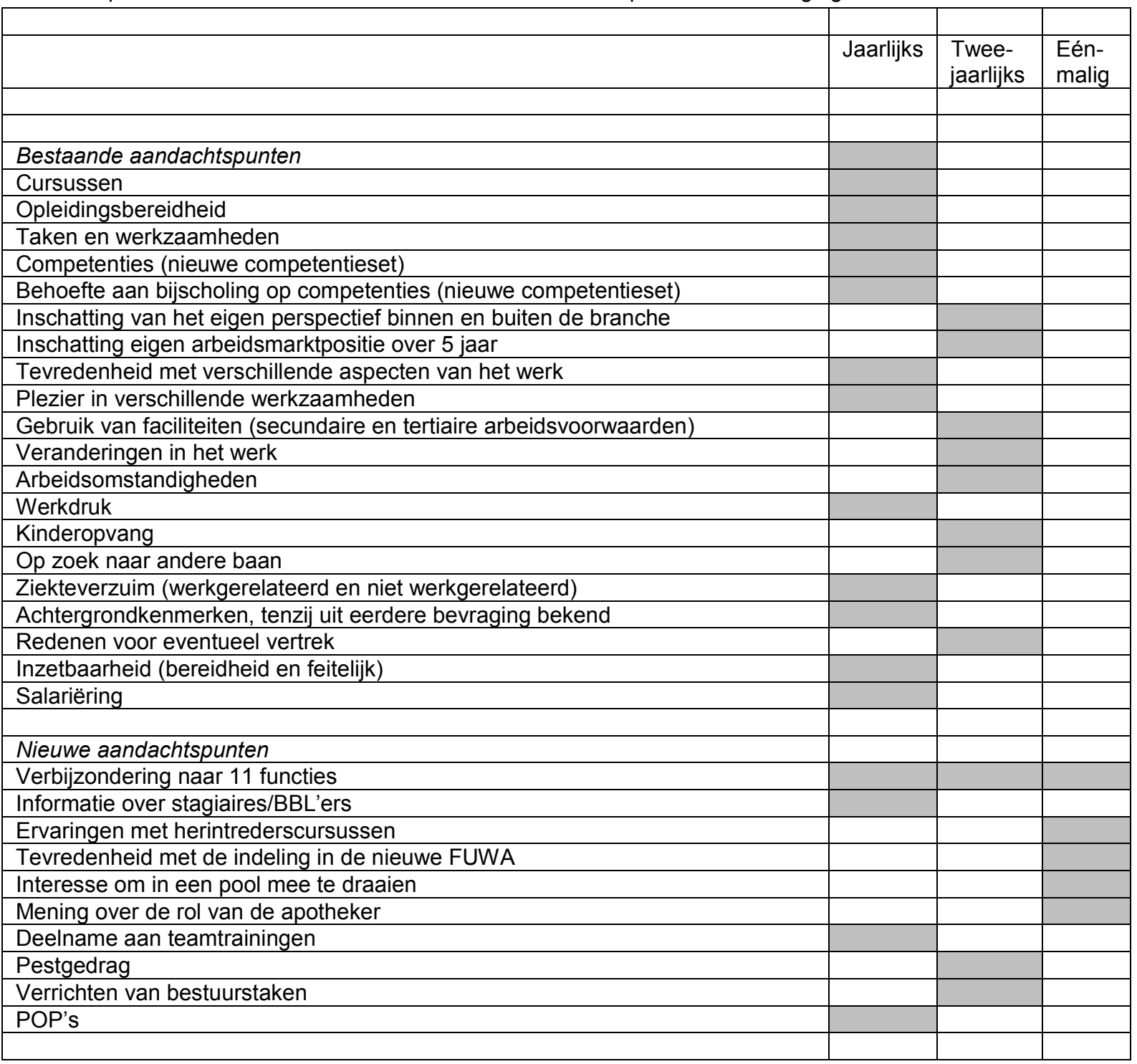




\subsection{Schoolverlatersonderzoek}

\section{Opzet}

De informatie die een onderzoek onder schoolverlaters van de opleiding tot apothekersassistent oplevert, wordt door bijna de helft van de gesprekspartners als belangrijk ervaren. Nog eens $46 \%$ van de respondenten beschouwt deze informatie als zeer belangrijk. In de tweede cyclus van de Arbeidsmarktmonitor Apotheekbranche zal het schoolverlatersonderzoek dan ook aandacht krijgen. Het ligt daarbij overigens niet voor de hand dezelfde groep schoolverlaters weer opnieuw te benaderen. Het gaat immers telkens om een nieuw cohort schoolverlaters. Voorgesteld wordt om deze nieuwe schoolverlaters te bevragen door aan te sluiten bij het onderzoek Registratie van Uitstroom en Bestemming van Schoolverlaters (RUBS), dat het ROA jaarlijks verricht onder schoolverlaters van alle reguliere BVE-opleidingen. In dit RUBS onderzoek worden schoolverlaters ondervraagd over de gevolgde opleiding en hun arbeidsmarktpositie anderhalf jaar na het verlaten van de opleiding.

In het kader van de Arbeidsmarktmonitor voor de Apotheekbranche zijn twee groepen schoolverlaters interessant. In de eerste plaats betreft het de schoolverlaters van de opleiding tot apothekersassistent, van zowel de BOL als de BBL variant. Zij vormen de uitstroom uit de opleiding en kunnen informatie verschaffen over de keuze tot verder leren of gaan werken en over de aansluiting tussen opleiding en werk. Een belangrijk punt in dit opzicht is dat van de 31 ROC's die een opleiding tot apothekersassistent aanbieden er slechts 8 hebben deelgenomen aan de RUBS enquête in 2001. Om tot een behoorlijk aantal responderende schoolverlaters van de opleiding tot apothekersassistent te komen, zullen er sterkere inspanningen gedaan moeten worden om de ROC's bij dit onderzoek te betrekken.

In de tweede plaats gaat het om de schoolverlaters van het VMBO die voor een vervolgopleiding als apothekersassistent kiezen. Zij vormen als het ware de instroom in de opleiding. Naar verwachting zal het aantal VMBO'ers dat voor een opleiding als apothekersassistent kiest slechts in kleine aantallen in het RUBS onderzoek vertegenwoordigd zijn. Dit onderzoek betreft immers een steekproef onder alle VMBO'ers. Om meer informatie over deze specifieke groep te verzamelen, is een apart scholierenonderzoek wellicht de beste opzet. Hierop komen we in paragraaf 4.6 terug.

De schoolverlatersonderzoeken van het ROA bevatten een aantal standaard vragen over competenties, de (kwalitatieve) aansluiting tussen opleiding en beroep en de keuze voor werk of een vervolgopleiding. De mogelijkheid bestaat om deze standaard vragenlijst voor de schoolverlaters van de opleiding tot apothekersassistent aan te vullen met een aantal specifieke vragen door een inlegvel aan de vragenlijst toe te voegen.

Het schoolverlatersonderzoek van het ROA vindt ieder jaar in september plaats. Dit betekent dat voor de tweede cyclus de metingen van september 2003, september 2004 of september 2005 zouden kunnen worden gebruikt. Gezien de planning van deze grootschalige onderzoeken, kan de mogelijkheid voor een inlegvel met specifieke vragen voor schoolverlaters van de opleiding tot apothekersassistent pas vanaf de meting in 2004 geboden worden. 


\section{Aandachtspunten}

Het schoolverlatersonderzoek kan in de eerste plaats informatie opleveren over het aantal gediplomeerde schoolverlaters en de bestemming van deze schoolverlaters. Deze informatie wordt door de sleutelpersonen als (zeer) belangrijk ervaren.

Ook voor informatie over de aansluiting tussen opleiding en beroep is de belangstelling (zeer) groot. In de rapportage zal hier dan ook de nodige aandacht aan besteed worden. Onderwerpen waarvoor de belangstelling wat minder groot is, zoals de wijze waarop de huidige baan gevonden is en intredewerkloosheid, kunnen wat minder nadruk krijgen. Omdat het onderzoek onder schoolverlaters van de opleiding tot apothekersassistent geheel plaatsvindt binnen het jaarlijkse RUBS onderzoek, zal er in de basisvragenlijst in principe niets veranderen.

Nieuwe elementen die in de standaardvragenlijst van het RUBS-onderzoek niet aan de orde komen, maar die wel van belang zijn, zouden in een inlegvel in september 2004 opgenomen kunnen worden. Eén van die elementen is bijvoorbeeld de 'nieuwe' competentieset en de mate waarin scholieren tijdens hun opleiding informatie over de branche krijgen.

\subsection{Onderzoek onder niet-participerenden}

\section{Opzet}

Er is eveneens duidelijk belangstelling voor het voortzetten van het onderzoek onder het 'onbenutte arbeidspotentieel' voor de (openbare) apotheken. Het gaat hier om de mensen die in het verleden ooit in een apotheek hebben gewerkt, maar hiermee op een gegeven moment zijn gestopt. Met name informatie over de redenen van vertrek, de bereidheid om weer in de openbare apotheek te komen werken en de belemmeringen bij terugkeer vinden velen belangrijk.

Het onbenut arbeidspotentieel bestaat uit alle gediplomeerde apothekersassistenten die niet in de openbare apotheek werken. In de periode 1999-2000 waren dit ongeveer 16.500 mensen. Aangezien het niet mogelijk is om deze hele groep te achterhalen, richten we ons, net als in de eerste cyclus, op potentiële herintreders. Dit zijn alle niet-participerende assistenten die ooit in de openbare apotheek gewerkt hebben en dus bij het Pensioenfonds Medewerkers Apotheken (PMA) ingeschreven staan. Deze groep mag zich ook zeer in de belangstelling van de gesprekspartners verheugen. De repons onder de potentiële herintreders bedroeg in de eerste cyclus 49\% (1.836 assistenten).

Omdat velen de gegevens over de uitstroom uit de openbare apotheek belangrijk vinden, is het interessant om speciale aandacht te vragen voor de deelname van apothekersassistenten die de afgelopen twee jaar de openbare apotheek hebben verlaten. Uit cijfers van het PMA blijkt dat er ieder jaar zo'n 500 apothekersassistenten de openbare apotheek uitstromen. Deze groep assistenten zou een aantal aanvullende vragen over de redenen van vertrek kunnen beantwoorden. 
Het PMA houdt geen informatie bij over de bestemming van apothekersassistenten na uittrede. Hierdoor is het niet mogelijk om voor het uitzenden van de enquête al onderscheid te maken tussen de verschillende groepen niet-participerenden. Er kunnen dus geen vragenlijsten met aparte vragen voor assistenten die werkloos zijn, elders werk hebben gevonden of zich zijn gaan bezig houden met zorgtaken verstuurd worden. Wel zal bij de bespreking van de resultaten aandacht besteed worden aan deze verschillende groepen niet-participerenden. Aan de keuze om niet als apothekersassistent werkzaam te zijn en aan hun bereidheid om weer naar de openbare apotheek terug te keren liggen voor de verschillende groepen immers vaak totaal andere overwegingen ten grondslag.

Gezien het feit dat de belangstelling voor informatie uit het onderzoek onder het onbenutte arbeidspotentieel ietwat geringer is dan voor informatie uit de andere onderdelen van de Arbeidsmarktmonitor Apotheekbranche, zou een enquête onder niet-participerenden niet jaarlijks, maar iedere twee jaar gehouden kunnen worden. $40 \%$ van de gesprekspartners vindt dit een goede frequentie. Dit betekent dat deze enquête in het voorjaar van 2004 zou kunnen plaatsvinden.

Tabel 4.3

Aandachtspunten van het onderzoek naar het onbenutte arbeidspotentieel en frequentie van bevraging

\begin{tabular}{|l|l|l|}
\hline & & \\
\hline & Tweejaarlijks & Eénmalig \\
\hline & & \\
\hline Bestaande aandachtspunten & & \\
\hline Achtergrondkenmerken (leeftijd, geslacht en gezinssituatie) & & \\
\hline Onderscheid niet participerend/werkloos/werkend buiten openbare apotheek & & \\
\hline Redenen om te stoppen & & \\
\hline Bereidheid weer te gaan werken (in de openbare apotheek of elders) & & \\
\hline Gewenste aantal werkuren & & \\
\hline Belemmeringen bij de terugkeer & & \\
\hline Termijn waarop men weer wil gaan werken (in de apotheek of elders) & & \\
\hline Voorwaarden waaronder men weer wil werken (in de apotheek of elders) & & \\
\hline & & \\
\hline Nieuwe aandachtspunten & & \\
\hline Onderscheid arbeidsgeschikt/gedeeltelijk arbeidsongeschikt/arbeidsongeschikt & & \\
\hline Bereidheid deel te nemen aan een assistentenpool & & \\
\hline
\end{tabular}

\section{Aandachtspunten}

Voorgesteld wordt het onderzoek naar het onbenutte arbeidspotentieel vooralsnog uitsluitend te richten op de apothekersassistenten. Daarbij is het gewenst om te vragen naar achtergrondkenmerken, de redenen om te stoppen, de bereidheid om naar de openbare apotheek terug te keren en de belemmeringen bij terugkeer (zie tabel 4.3). Ook kan worden ingegaan op de voorwaarden waaronder men zou willen terugkeren en de termijn waarop men denkt een eventuele terugkeer te kunnen realiseren. Daarbij zou de mogelijkheid moeten openstaan om onderscheid te maken tussen niet-participerenden die terug zouden willen naar de apotheekbranche, niet-participerenden die weliswaar weer willen gaan werken, maar niet in de apotheekbranche en niet-participerenden die voorlopig helemaal niet van plan zijn her in te treden. 
Het zou wenselijk zijn om (gedeeltelijk) arbeidsongeschikten als aparte groep te onderzoeken. Hierbij kunnen onder andere specifieke vragen aan de orde komen over de mate van arbeidsongeschiktheid en over welke taken en werkzaamheden gedeeltelijk arbeidsongeschikten op zich kunnen nemen. De groep geheel of gedeeltelijk arbeidsongeschikten is echter relatief klein (zo'n 700 personen).

Ten slotte zou de vraag kunnen worden toegevoegd of men al dan niet zou willen deelnemen aan een apothekersassistentenpool.

\subsection{Toekomstverkenning}

Opzet

In een dynamische arbeidsmarkt is het van belang regelmatig vooruit te blikken. In de eerdere toekomstverkenning van de arbeidsmarkt voor apothekersassistenten zijn er daarom prognoses gemaakt van de verwachte knelpunten op de arbeidsmarkt op de middellange termijn. Ook wordt er gekeken naar de mogelijke invloeden van overheidsbeleid en van gevoerd HRM beleid in de openbare apotheek. Uit hoofdstuk 2 bleek dat een dergelijke toekomstverkenning voor alle gesprekspartners een zeer belangrijke informatiebron van de Arbeidsmarktmonitor Apotheekbranche is.

Een meerderheid van de gesprekspartners geeft de voorkeur aan een jaarlijkse update van deze prognosecijfers. Eén op de drie is voorstander van een tweejaarlijkse toekomstverkenning. Aangezien de prognoses betrekking hebben op een wat langere periode en dus niet zo snel veranderen, lijkt deze laatste opzet ons de meest voor de hand liggende. De eerstvolgende toekomstverkenning zou dan betrekking kunnen hebben op de periode 2005-2012. Hierbij kan ook aandacht besteed worden aan de prognoses van de arbeidsmarkt op de kortere termijn (2005-2007).

De toekomstverkenning van de arbeidsmarkt voor apothekersassistenten is gebaseerd op gegevens van onder andere het Pensioenfond Medewerkers Apotheken (PMA), de Stichting Farmaceutische Kengetallen (SFK) en het Centraal Bureau voor de Statistiek (CBS). Daarnaast wordt informatie gebruikt uit de hierboven genoemde enquêtes onder werkgevers, werknemers, schoolverlaters en niet-participerende apothekersassistenten. Het is dan ook verstandig om de toekomstverkenning te plannen wanneer alle andere onderdelen van de tweede cyclus afgesloten zijn. Dit zou in het voorjaar van 2005 zijn.

\section{Aandachtspunten}

Volgens de geïnterviewde sleutelpersonen is het belangrijk om bij de prognoses rekening te houden met de consequenties van maatregelen van de overheid, de reacties van de KNMP hierop en de implicaties van het gevoerde HRM beleid in de openbare apotheek. Ook de rol van automatisering en de verwachte ontwikkelingen met betrekking tot de gevraagde competenties zijn volgens velen belangrijke aandachtspunten.

In navolging van eerdere toekomstverkenningen voor de apotheekbranche, zou de nieuwe toekomstverkenning primair de arbeidsmarkt voor apothekersassistenten kunnen trachten te 
voorspellen. Er zou echter ook geprobeerd kunnen worden indicaties te verkrijgen van de verwachte arbeidsmarktsituatie voor de overige functiecategorieën.

\subsection{Mogelijke nieuwe instrumenten}

Uit de gesprekken komt als algemeen punt naar voren dat de eerste cyclus in een aantal opzichten te beperkt is gebleven, omdat een aantal relevante groepen ten onrechte buiten beschouwing is gebleven. In deze paragraaf bespreken we een aantal nieuwe instrumenten dat deze lacunes zou kunnen opvullen.

\section{Onderzoek onder scholieren en voortijdig schoolverlaters}

Allereerst is onderzoek gewenst onder scholieren die de opleiding tot apothekersassistent volgen. Weliswaar wordt schoolverlaters gevraagd naar hun mening over het curriculum en de aansluiting van opleiding en beroep, maar over scholieren zelf is weinig tot niets bekend. Waarom kiezen leerlingen nu juist voor deze opleiding en hoe kwamen zij in aanraking met de opleiding? Wat voor mensen zitten er op de opleiding (leeftijd, etniciteit, geslacht)? Wat vinden zij van het niveau van de opleiding, het curriculum en bijvoorbeeld de beroepspraktijkvorming? Hoeveel tijd zijn zij kwijt aan huiswerk? En hebben zij thuis voldoende faciliteiten om huiswerk te maken?

Niet alleen scholieren, maar ook voortijdig schoolverlaters kunnen in het kader van dit onderzoek worden bevraagd. Waarom houden leerlingen bijvoorbeeld voortijdig op met de opleiding? Wat gaan zij in plaats van de opleiding doen? En wat zou er moeten veranderen om ze terug te halen naar de opleiding tot apothekersassistent?

Om een antwoord te kunnen formuleren op deze en andere vragen over de opleiding zelf en de mening van scholieren hierover zal een nieuw instrument moeten worden ontwikkeld. Men kan zich overigens afvragen of deze 'onderwijsmonitor' deel zou moeten uitmaken van de arbeidsmarktmonitor. Wel dient de mogelijkheid tot koppeling van de resultaten van het scholierenonderzoek aan de resultaten van de andere instrumenten open te staan.

\section{Onderzoek onder tweede apothekers}

Tweede apothekers hebben in de eerste cyclus weinig aandacht gekregen. Informatie over deze groep medewerkers is echter volgens tweederde van de sleutelpersonen echter wel belangrijk. Derhalve lijkt het zinvol om naast het bestaande werknemersonderzoek een onderzoek te doen onder tweede apothekers. In dit onderzoek zouden vragen aan bod kunnen komen over de rol van tweede apothekers als werknemers en hun rol als leidinggevende.

Daarbij zou enerzijds gezorgd moeten worden voor mogelijkheden om tweede apothekers te vergelijken met andere medewerkers, maar ook met mogelijkheden om hun rol te vergelijken met die van zelfstandige apothekers en apothekers in loondienst bij een ketenapotheek (beherend apothekers). Een probleem hierbij is dat de steekproef onder de tweede apothekers niet getrokken kan worden uit de databestanden van het PMA. Er zou derhalve 
gezocht moeten worden naar goede alternatieven. Mogelijk biedt de ledenlijst van de KNMP hierbij uitkomst.

\section{Klanttevredenheidsonderzoek}

Om de klanttevredenheid te kunnen betrekken bij de Arbeidsmarktmonitor Apotheekbranche zal deze in een apart onderzoek moeten worden bepaald. De voorkeur gaat hierbij uit naar jaarlijks klanttevredenheidsonderzoek onder een representatieve selectie van de aan de arbeidsmarktmonitor deelnemende apotheken. Per apotheek zouden zo'n 50 à 100 klanten kunnen worden bevraagd om een idee te krijgen van de tevredenheid over onder anderen de informatievoorziening, de klantvriendelijkheid, de openingstijden e.d. Het klanttevredenheidsonderzoek is derhalve een omvangrijk onderzoek dat overigens geen onderdeel hoeft te zijn van de arbeidsmarktmonitor zelf. Wel zou het van belang zijn dat (resultaten van) klanttevredenheidsonderzoek direct koppelbaar zijn aan de gegevens uit de werkgeversenquête van de arbeidsmarktmonitor, zodat ze kunnen worden meegenomen bij analyses van bijvoorbeeld het rendement op HRM investeringen en de effecten van de competenties en de gevolgde bijscholing van het personeel

\section{Onderzoek ziekenhuisapotheken}

De eerste cyclus van de arbeidsmarktmonitor richtte zich op de openbare apotheek. Er is echter grote interesse voor eventuele verschillen tussen het werken in de openbare apotheken en de ziekenhuisapotheken. Het takenpakket van de apothekersassistenten in de ziekenhuisapotheken zou bijvoorbeeld anders kunnen zijn dan dat van de apothekersassistenten in de openbare apotheek. Bovendien zouden ziekenhuisapotheken zich meer met het uitreiken van medicijnen aan bijvoorbeeld verzorgingstehuizen gaan bezighouden.

Om deze en andere vooronderstellingen en verwachtingen te kunnen toetsen is het van belang dat gegevens worden verzameld over ziekenhuisapotheken, de apothekersassistenten die daar werkzaam zijn en bijvoorbeeld de taken en werkzaamheden die deze assistenten verrichten.

Om onderzoek te kunnen doen onder de naar schatting 100 ziekenhuisapotheken (op 31 december 2001) die Nederland rijk is, zou aansluiting gezocht moeten worden bij de Nederlandse Vereniging voor Ziekenhuisapotheken (NVZA). Bij voorkeur zouden de vragenlijsten van het werkgeversonderzoek en het werknemersonderzoek zoveel mogelijk ongewijzigd ook in ziekenhuisapotheken moeten worden uitgezet.

\subsection{Overzicht instrumenten Arbeidsmarktmonitor Apotheekbranche}

Tabel 4.4 geeft een overzicht van de verschillende instrumenten waaruit de tweede cyclus van de Arbeidsmarktmonitor Apotheekbranche zou kunnen bestaan. Tevens wordt aangegeven wanneer de dataverzameling zou kunnen plaatsvinden. 


\section{Tabel 4.4}

Overzicht instrumenten Arbeidsmarktmonitor Apotheekbranche naar moment van dataverzameling

Instrument

Periode van dataverzameling

Werkgeverspanel

Werkgeverspanel verzuim/ vacatures

Werknemerspane

Schoolverlatersonderzoek

Onderzoek onbenut arbeidspotentiee

Toekomstverkenning
September 2003, eerste meting

September 2004, tweede meting

leder kwartaal

November 2003, eerste meting

November 2004, tweede meting

September 2003

September 2004 (inlegvel)

Maart 2005

Maart 2006 


\section{Bijlage 1: Gesprekspartners}

Mevrouw L. Havermans en de heer B. Vincken namens GEHE

De heer C. Frerichs namens Maetis ARBO

De heer S. van de Ven, mevrouw E. de Vaal en mevrouw M. Veldhuizen namens SBA

Mevrouw M. Kamp en mevrouw G. Kelder namens VWS

De heer P. Föster namens Brocacef

Mevrouw B. van der Linden

De heer M. van Aken namens PMA

Mevrouw C. Dijken namens KNMP/WINAp

De heer F. Schüsler namens KNMP/Resa

De heer H. Philipse namens KNMP hoofdbestuur

De heer $\mathrm{H}$. Overgaag namens KNMP, afdeling arbeidsvoorwaarden

De heer A. Rutgers namens Departement Hart van Brabant

Mevrouw E. van Saaze namens Departement Utrecht

De heer L. Huynen namens Departement Limburg

De heer R. Kooter namens ROC Mon3aan

De heren L. Tinke en F. Baart namens SFK

De heren J. van Amelsfoort en R. van de Berg namens OVDB

De heren P. Verhoog en R. Burghouts namens Remedium

Mevrouw H. van Wezel-Veroude namens de BVE Raad

Mevrouw N. Winters namens de VJA 